\title{
Contrasting trophic interactions of microbial and copepod communities in a fjord ecosystem, Chilean Patagonia
}

\author{
Cristian A. Vargas ${ }^{1,2, *}$, Rodrigo A. Martínez ${ }^{1}$, Humberto E. González ${ }^{2,3,4}$, \\ Nelson Silva ${ }^{5}$ \\ ${ }^{1}$ Aquatic System Unit, Environmental Sciences Center EULA Chile, Universidad de Concepción, PO Box 160-C, Concepción, Chile \\ ${ }^{2}$ Patagonian Ecosystems Research Center (CIEP), Bilboa 449, Coyhaique, Chile \\ ${ }^{3}$ Institute of Marine Biology 'Dr. Jürgen Winter', Universidad Austral de Chile, PO Box 567, Valdivia, Chile \\ ${ }^{4}$ Center for Oceanographic Research in the eastern South Pacific (COPAS), PO Box 160-C, Concepción, Chile \\ ${ }^{5}$ School of Marine Sciences, P. Universidad Católica de Valparaíso, PO Box 1020, Valparaíso, Chile
}

\begin{abstract}
Trophic interactions between microbial and copepod communities were studied during winter and under spring-bloom conditions in the Reloncaví Fjord, Chile, and adjacent channels. Grazing by heterotrophic nanoflagellates (HNF) and microzooplankton was estimated using the sizefractionation method. Simultaneously, copepod grazing experiments using naturally occurring plankton assemblages were performed. Contrasting food environments for planktonic consumers were found between winter and spring, with biomasses of prey organisms $<1 \mu \mathrm{g} \mathrm{Cl}^{-1}$ during winter and ca. $150 \mu \mathrm{g} \mathrm{Cl}^{-1}$ during spring. The highest bacterial and phytoplankton biomasses were observed during spring, when autotrophic biomass in the fjord and adjacent channels mostly consisted of diatoms. Most grazers in the $<20 \mu \mathrm{m}$ filtered fraction belonged to the HNF, which exhibited maximum ingestion during winter, whereas the highest grazing by microzooplankton occurred in spring. Grazing experiments showed contrasting trophic interactions between copepods and their prey. In winter, copepod grazing rates were among the lowest reported for oligotrophic areas $\left(<0.2 \mu \mathrm{g} \mathrm{C}\right.$ ind.$\left.^{-1} \mathrm{~d}^{-1}\right)$, while $\mathrm{HNF}$ and dinoflagellates contributed significantly to the total average daily ingestion of prey items $\left(>50 \% \mathrm{~d}^{-1}\right)$. During spring, small and large copepods exhibited prey ingestion rates of 2 to 3 and ca. 6 to $10 \mu \mathrm{g} \mathrm{C}$ ind. ${ }^{-1} \mathrm{~d}^{-1}$, respectively. In such a contrasting food environment, copepods have to alleviate the effects of food scarcity either by modifying their metabolic demands or by switching their diet to microbial organisms that are available during periods of low diatom biomass. The present study reveals that, even under productive spring-bloom conditions, the less-abundant heterotrophic protists constitute a substantial proportion (ca. $30 \%$ of the daily consumption) of the copepod diet in fjord ecosystems.
\end{abstract}

KEY WORDS: Microbial communities - Heterotrophic nanoflagellates - Ciliates - Dinoflagellates · Copepods $\cdot$ Fjord ecosystems

Resale or republication not permitted without written consent of the publisher

\section{INTRODUCTION}

Fjords and estuaries are important sites with respect to carbon and nutrient dynamics at the land-sea interface and play an important role in biological productivity and carbon cycling within aquatic ecosystems (Burrel 1988). They are heavily influenced by both river discharge and ice melt run-off. This freshwater input may impact the hydrography of the upper water column, and may also have direct effects on the structure and function of the plankton community (Nielsen $\&$ Andersen 2002).

The succession of the phytoplankton community of fjord ecosystems during the productive spring season varies locally and is typically determined by physical factors such as light, mixing, circulation patterns, tem- 
perature and salinity, and by biological factors such as competition and grazing activity (Antezana \& Hamamé 1999, Pizarro et al. 2000). It is known that micro- and meso-zooplankton grazing activity can affect the routes by which primary production (PP) moves through the pelagic food web, with implications for ecosystem functioning, as well as the retention and vertical export of organic carbon to the benthos (Vargas \& González 2004a).

Recently, Chilean fjords have received considerable attention in terms of investigations of their physical and biological oceanography, much of it arising from the increase in anthropogenic activities (e.g. fish farming, tourism, hydroelectric activities, among others) which may affect the functioning of these pristine ecosystems. There is evidence that plankton biomass and composition between different fjord ecosystems exhibit large variations (Palma \& Silva 2004, Pizarro et al. 2000). In nearshore areas, especially of fjords with inlets (i.e. under estuarine conditions), zooplankton communities are largely dominated by dense aggregations of cladocerans and meroplanktonic larvae of crustaceans mixed with an abundant, diverse community of epipelagic calanoid copepods, such as Calanus chilensis, Calanoides patagoniensis, Rhincalanus nasutus, and Paracalanus parvus (Marín \& Antezana 1985, Hirakawa 1989). During spring, the inshore waters are highly fertile, which is reflected by high rates of phytoplankton growth (Pizarro et al. 2000) and favours the abundance of planktonic herbivores and carnivores (Antezana \& Hamamé 1999, Palma \& Silva 2004). Therefore, the amount of carbon that is photosynthetically fixed during and after the spring bloom needs to be quantified, to allow a comparison of the feeding activities and trophic interactions of the dominant grazer groups with lower trophic levels. Due to the scarcity of information on the grazing activity of nanoflagellates, microzooplankton, and copepods in Chilean fjords, it is difficult to assess their quantitative and ecological importance in this ecosystem and to determine their true position and influence on food web dynamics and ecosystem functioning. In addition, no information is available on the clearance and ingestion rates of phytoplankton and microbial communities or on the factors regulating the feeding of dominant copepods in fjord ecosystems, which precludes any speculation concerning their potential role in the pelagic food web.

The first objective of the present study was to estimate the feeding activity of heterotrophic nanoflagellates (HNF) and the microzooplankton community on bacteria and flagellates. The second objective was to measure the clearance and ingestion rates of small and large copepods on natural assemblages of protozoa, including HNF, dinoflagellates and ciliates, and 5 dif- ferent fractions of microplankton, including phototrophic nanoflagellates (PNF), chain forming diatoms, pennate and centric diatoms, and dinoflagellates.

\section{MATERIALS AND METHODS}

Site and sampling. Experiments were conducted on board the RV 'Vidal Gormaz' during 2 cruises conducted in the Reloncaví Fjord, Reloncaví Sound, Ancud, and Corcovado Gulfs in northern Chilean Patagonia, (42 to $43^{\circ} \mathrm{S}, 72^{\circ} 5^{\prime} \mathrm{W}$; Fig. 1). Cruises were carried out during (1) austral winter, from 8 to 16 July 2006, and (2) austral spring, from 4 to 11 November 2006. Daily feeding experiments were conducted for $5 \mathrm{~d}$ each at an anchor station (Stn 5) and at 2 additional stations located in Reloncaví Sound and Ancud Gulf (in winter at Stns 3 and 16, and during spring at Stns 20 and 49) (Fig. 1).

Hydrography, nutrients, size-fractionated chlorophyll and particulate organic carbon. Continuous temperature and conductivity profiles were recorded with a CTD Seabird 19. Seawater samples for chlorophyll a (chl a) and phaeopigments (1 l), particulate organic carbon (POC) (0.5 to 1 l), and nutrient analysis $(50 \mathrm{ml})$ were collected at discrete depths $(1,5,10,25$, and $50 \mathrm{~m}$ ) with a Niskin bottle rosette system. Nitrate $\left(\mathrm{NO}_{3}{ }^{-}\right)$, phosphate $\left(\mathrm{PO}_{4}{ }^{3-}\right)$ and silicate $\left(\mathrm{Si}(\mathrm{OH})_{4}\right)$ con-

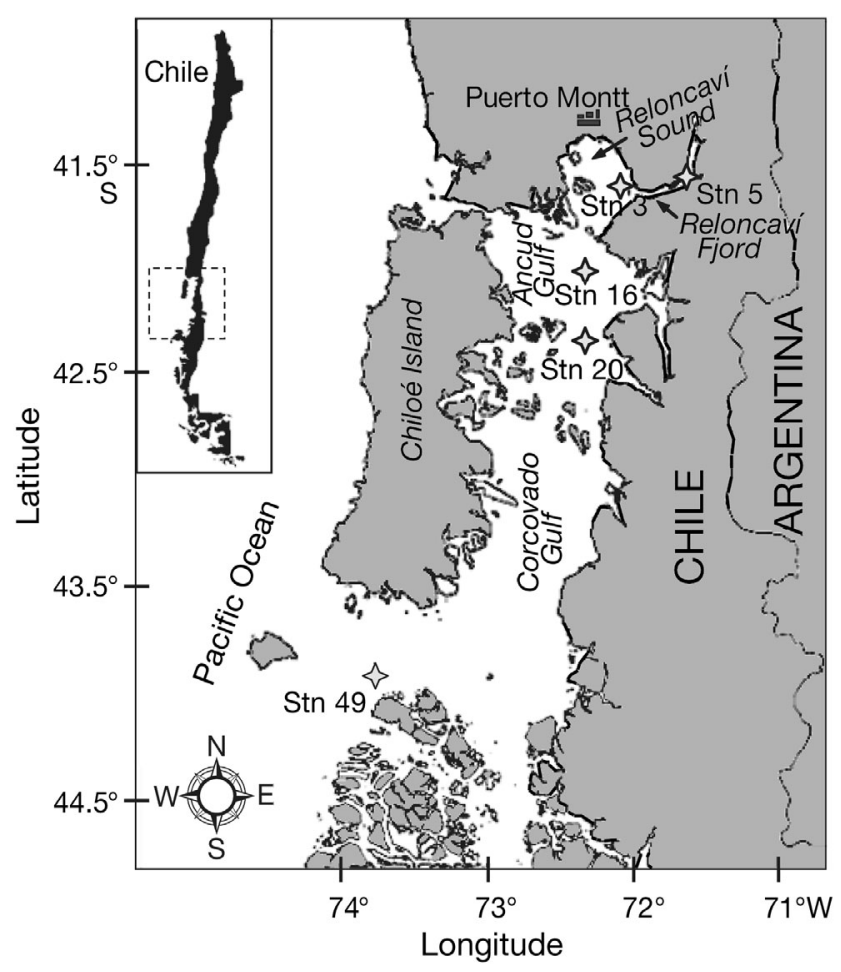

Fig. 1. Study area and location of the sampling stations in the Reloncaví Fjord and adjacent gulfs and channels 
centrations were measured with a nutrient autoanalyzer following Atlas et al. (1971). For chl $a$ and phaeopigments, triplicate samples of $200 \mathrm{ml}$ of seawater were filtered (MFS glass fibre filters with $0.7 \mu \mathrm{m}$ effective pore size), and immediately frozen $\left(-20^{\circ} \mathrm{C}\right)$ for later analysis using a Turner Designs TD-700 fluorometer. Acetone $(90 \% \mathrm{v} / \mathrm{v})$ was used for pigment extraction following standard procedures (Parsons et al. 1984). Water samples for POC analysis were filtered through pre-combusted MFS filters and frozen $\left(-20^{\circ} \mathrm{C}\right)$ for later analysis. POC content was analysed in a Europa Hydra 20-20 continuous flow isotope ratio mass spectrometer at the UC Davis Stable Isotope Facility Laboratory (USA) following combustion at $1000^{\circ} \mathrm{C}$ and using acetanilide as a standard (Bodungen et al. 1991).

Microbial grazing experiments. Nanoflagellate and microzooplankton grazing experiments were performed using the size fractionation method (Kivi \& Setälä 1995, Sato et al. 2007, Vargas et al. 2007). Water samples were collected from the fluorescence maxi- mum depth $\left(F_{\max }\right)$ with a 101 GoFlo bottle rosette system. After collection, seawater was size-fractioned by reverse filtration (using polycarbonate filters) into 3 fractions: $(1)<2 \mu \mathrm{m}$, containing mostly bacteria and cyanobacteria; $(2)<10 \mu \mathrm{m}$, containing mostly bacteria, cyanobacteria, PNF and HNF; (3) <115 $\mu \mathrm{m}$, containing the entire photo-heterotrophic community.

Triplicate batch cultures were incubated in $500 \mathrm{ml}$ bottles for 18 to $20 \mathrm{~h}$ (Table 1) in an incubator rack on deck, which was plumbed with running surface seawater to maintain the temperature more or less constant at $2^{\circ} \mathrm{C}\left( \pm 1^{\circ} \mathrm{C}\right)$. The contents of initial control bottles were immediately preserved with $2 \%$ Lugol's for phytoplankton counts, and a subsample was preserved in glutaraldehyde $(6.0 \% \mathrm{w} / \mathrm{v}$ in $0.2 \mu \mathrm{m}$ prefiltered seawater) for counts of bacteria and nanoflagellates. At the end of the incubation period, sub-samples were taken from all bottles and preserved in glutaraldehyde $(20 \mathrm{ml})$ and Lugol's (60 $\mathrm{ml}$ as above) for cell counts. Following Gifford (1993), grazing rates were estimated

Table 1. Grazing experiments conducted with nano- and microheterotrophic communities and various copepod species during austral winter and spring conditions. $\mathrm{n}$ : no. of replicate grazing bottles, $F_{\max }$ : depth of maximum fluorescence (m); density is given as means $\pm \mathrm{SD} ; \mathrm{CV}$ : Copepodite Stage V

\begin{tabular}{|c|c|c|c|c|c|c|c|c|}
\hline Expt & Stn & Date & Species/group & $F_{\max }$ & 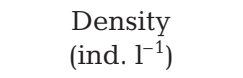 & $\begin{array}{c}\text { Size range } \\
(\mu \mathrm{m})\end{array}$ & $\begin{array}{l}\text { Duration } \\
\text { (h) }\end{array}$ & $\begin{array}{r}\text { Temp } \\
\left({ }^{\circ} \mathrm{C}\right)\end{array}$ \\
\hline \multirow[t]{3}{*}{1} & \multirow[t]{3}{*}{ Stn 5-Fjord } & \multirow[t]{3}{*}{9 Jul 2006} & Nanoheterotrophs & 10 & $7.2 \pm 2.4 \times 10^{3}$ & $2-20$ & 18.7 & 9 \\
\hline & & & Microhetetrophs & 10 & $0.03 \pm 0.02 \times 10^{3}$ & $20-110$ & 18.7 & 9 \\
\hline & & & Paracalanus parvus & 10 & 8 & $900-1200$ & 18.9 & 9 \\
\hline \multirow[t]{4}{*}{2} & \multirow[t]{4}{*}{ Stn 5-Fjord } & \multirow[t]{4}{*}{$11 \mathrm{Jul} 2006$} & Nanoheterotrophs & 20 & $8.0 \pm 1.7 \times 10^{3}$ & $2-20$ & 21.4 & 9 \\
\hline & & & Microhetetrophs & 20 & $0.1 \pm 0.05 \times 10^{3}$ & $20-110$ & 21.4 & 9 \\
\hline & & & Paracalanus parvus & 20 & 6 & $900-1100$ & 25.6 & 9 \\
\hline & & & Calanus chilensis & 20 & 4 & $1500-1600$ & 25.7 & 9 \\
\hline \multirow[t]{4}{*}{3} & \multirow[t]{4}{*}{ Stn 5-Fjord } & \multirow[t]{4}{*}{13 Jul 2006} & Nanoheterotrophs & 10 & $7.0 \pm 5.1 \times 10^{3}$ & $2-20$ & 22.9 & 9 \\
\hline & & & Microhetetrophs & 10 & $0.08 \pm 0.02 \times 10^{3}$ & $20-110$ & 22.9 & 9 \\
\hline & & & Calanus chilensis & 10 & 2 & $1800-2000$ & 22.8 & 9 \\
\hline & & & Rhincalanus nasutus & 10 & 2 & $4200-4600$ & 22.6 & 9 \\
\hline \multirow[t]{2}{*}{4} & \multirow[t]{2}{*}{ Stn 3-Gulf } & \multirow[t]{2}{*}{14 Jul 2006} & Paracalanus parvus & 10 & 6 & 850-1000 & 21.7 & 10 \\
\hline & & & Calanus chilensis & 10 & 2 & $1900-2000$ & 20.2 & 10 \\
\hline \multirow[t]{2}{*}{5} & \multirow[t]{2}{*}{ Stn 16-Gulf } & \multirow[t]{2}{*}{15 Jul 2006} & Paracalanus parvus & 10 & 6 & $900-1000$ & 21.9 & 9 \\
\hline & & & Acartia tonsa & 10 & 6 & $900-1000$ & 22.0 & 9 \\
\hline \multirow[t]{4}{*}{6} & \multirow[t]{4}{*}{ Stn 5-Fjord } & \multirow[t]{4}{*}{4 Nov 2006} & Nanoheterotrophs & 20 & $2.7 \pm 4.9 \times 10^{4}$ & $2-20$ & 22 & 10 \\
\hline & & & Microhetetrophs & 20 & $0.10 \pm 0.04 \times 10^{3}$ & $20-110$ & 22 & 10 \\
\hline & & & Calanus chilensis & 20 & 2 & $1800-2000$ & 22.9 & 10 \\
\hline & & & Paracalanus parvus & 20 & 6 & $900-1100$ & 22.7 & 10 \\
\hline \multirow[t]{4}{*}{7} & \multirow[t]{4}{*}{ Stn 5-Fjord } & \multirow{4}{*}{6 Nov 2006} & Nanoheterotrophs & 15 & $3.8 \pm 3.4 \times 10^{4}$ & $2-20$ & 25 & 11 \\
\hline & & & Microhetetrophs & 15 & $0.13 \pm 0.04 \times 10^{3}$ & $20-110$ & 25 & 11 \\
\hline & & & Paracalanus parvus & 15 & 6 & $900-1100$ & 23.1 & 11 \\
\hline & & & Neocalanus sp. & 15 & 2 & $2200-2500$ & 23.1 & 11 \\
\hline \multirow[t]{4}{*}{8} & \multirow[t]{4}{*}{ Stn 5-Fjord } & \multirow[t]{4}{*}{8 Nov 2006} & Nanoheterotrophs & 15 & $5.1 \pm 5.5 \times 10^{4}$ & $2-20$ & 31 & 11 \\
\hline & & & Microhetetrophs & 15 & $0.31 \pm 0.13 \times 10^{3}$ & $20-110$ & 31 & 11 \\
\hline & & & Calanus chilensis & 15 & 2 & $1800-2000$ & 24.9 & 11 \\
\hline & & & Rhincalanus nasutus & 15 & 2 & $4200-4500$ & 24.5 & 11 \\
\hline \multirow[t]{2}{*}{9} & \multirow[t]{2}{*}{ Stn 20-Gulf } & \multirow[t]{2}{*}{9 Nov 2006} & Paracalanus parvus & 10 & 8 & $900-1100$ & 21.8 & 11 \\
\hline & & & Rhincalanus nasutus & 10 & 2 & $4300-4600$ & 21.3 & 11 \\
\hline \multirow[t]{2}{*}{10} & \multirow{2}{*}{ Stn 49-Gulf } & 10 Nov 2006 & Centropages brachiatus & 10 & 4 & $1300-1400$ & 25.1 & 10 \\
\hline & & & Rhincalanus nasutus & 10 & 2 & $4300-4600$ & 24.6 & 10 \\
\hline
\end{tabular}


by comparing prey growth rates in the presence and absence of predators, selected by reverse filtration as follows: size fractions (1) and (2) were compared for HNF grazing, and (2) and (3) for microzooplankton (ciliates and dinoflagellates) grazing on nanoflagellates (both PNF and HNF). A minimum of 500 bacterial cells and 100 nanoflagellates were counted per bottle, and a $50 \mathrm{ml}$ Utermöhl sedimentation chamber was fully analysed for ciliates and dinoflagellate abundance.

Copepod feeding experiments. For estimates of copepod grazing, animals were collected by slow vertical hauls in the upper $20 \mathrm{~m}$ of the water column using a WP-2 net (mesh size $200 \mu \mathrm{m}$ ) with a large non-filtering cod end (ca. 40 to $60 \mathrm{l}$ ). Within $1 \mathrm{~h}$ after collection, undamaged copepods were sorted under an OLYMPUS SZ51 stereomicroscope, transferred to $200 \mathrm{ml}$ beakers and stored at in situ temperature until setting up the experiment (Table 1). Water for the incubations was collected from the $F_{\max }$ with a clean 101 GoFlo bottle-rosette system and subsequently screened through a $200 \mu \mathrm{m}$ net to remove most grazers. The animals were pipetted into $500 \mathrm{ml}$ (for small copepods) and $1000 \mathrm{ml}$ (for large calanoid copepods) acid-washed polycarbonate bottles containing ambient water loaded with natural food assemblages of microplankton. The bottles were tightly capped after filling to avoid air bubbles. Three control bottles without animals and 3 bottles with 2 to 4 animals each were placed in an incubator rack on deck for 19 to $25 \mathrm{~h}$. The incubation bottles were mixed by hand every hour and, to some extent, by the motion of the ship. Copepod concentrations in experimental bottles ranged from 4 to 8 ind. $\mathrm{l}^{-1}$ (Table 1). Initial control bottles were immediately preserved with $2 \%$ Lugol's, and a subsample was preserved in glutaraldehyde (as above). At the end of the incubation, sub-samples from all bottles were taken and preserved in glutaraldehyde $(20 \mathrm{ml})$ for nanoflagellate counts and in Lugol's (60 ml, as above) for cell concentration. Carbon content of the animals was calculated using weight-length regressions from the literature (e.g. Gorsky et al. 1988).

Cell counts and calculation of clearance and ingestion rates. Bacterial counting was done using epifluroescence microscopy and following the methodology of Porter \& Feig (1980). Between 2 and $5 \mathrm{ml}$ of seawater containing bacteria were stained with 4,6-diamidino-2-phenylindole (DAPI) to a final concentration of $72 \mu \mathrm{M}$ and collected on black polycarbonate filters ( $25 \mathrm{~mm}$ diameter, $0.2 \mu \mathrm{m}$ pore size). For the enumeration of nanoflagellates, subsamples were filtered on a $0.8 \mu \mathrm{m}$ polycarbonate membrane filter, stained with Proflavine $(0.033 \% \mathrm{w} / \mathrm{v}$ in distilled water) following to Haas (1982), and fixed with glutaraldehyde (as above) for subsequent analysis. Both bacteria and nanoflagellates were counted with an inverted micro- scope OLYMPUS IX-51 equipped with UV model UMWU2 (width band pass 330-385 nm) and FITC model U-MWB2 (width band pass 450 to $480 \mathrm{~nm}$ ) filter sets. Both PNF and HNF were divided into 2 groups: $<5 \mu \mathrm{m}$ and 5 to $20 \mu \mathrm{m}$, and PNF cells were identified by autofluorescence. Biovolumes were converted to carbon content using the equation of Chrzanowski \& Šimek (1990). Large cells were counted under the same inverted microscope. Subsamples of $50 \mathrm{ml}$ were allowed to settle for $24 \mathrm{~h}$ in Utermöhl sedimentation chambers before diatoms, dinoflagellates and ciliates were identified, counted and measured under the microscope. Plasma volumes were calculated (Edler 1979) and averaged from a minimum of 50 cells per species. Biovolumes of ciliates were calculated assuming conical shapes with length:diameter ratios of 1.25 for ciliates $<50 \mu \mathrm{m}$ and 2.0 for ciliates $>50 \mu \mathrm{m}$ (Tiselius 1989). We assumed carbon:plasma volume ratios of $0.11 \mathrm{pgC}$

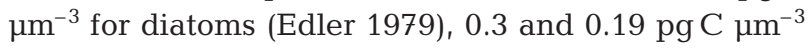
for heavily thecate and athecate dinoflagellates forms (E. J. Lessard unpubl. data fide Gifford \& Caron 2000), and $0.148 \mathrm{pgC} \mathrm{um}^{-3}$ for ciliates (Ohman \& Snyder 1991).

Clearance and ingestion rates, measured as cell removal, were calculated following Frost (1972) for the following groups: PNF and $\operatorname{HNF}(<5 \mu \mathrm{m}$ and 5 to $20 \mu \mathrm{m})$, dinoflagellates, silicoflagellates, ciliates, pennate, solitary centric, and chain forming diatoms. Clearance was calculated only when the difference in prey concentration between control and experimental bottles proved to be significant $(t$-test, $\mathrm{p}<0.05)$. Food selectivity was determined using the selectivity coefficient $(\alpha)$, which relates ingestion rates of the different food types with their availability (Chesson, 1978). The parameter $\alpha$ calculates capture probability based on the probability of prey encounter:

$$
\alpha=\left(r_{i} / p_{i}\right) / \Sigma\left(r_{i} / p_{i}\right)
$$

where $r_{i}$ is the proportion of the prey $i$ in the diet, $p_{i}$ is the proportion of the prey $i$ in the environment, and $\Sigma \alpha=1$. If the total number of prey species is $(m)$, then when $\alpha=1 /(m)$, there is no evidence of selection. When $\alpha>1 /(m)$, selective copepod predation may have occurred. Alternatively, if $\alpha<1 /(m)$, prey avoidance may have occurred.

One of the biases of the incubation method is that the prey suspension contains several trophic levels. In order to correct for this bias, a 3-component equation template, which considers interactions among 3 grazers in differently structured food chains (Tang et al. 2001), was applied. Based on the abundance of the components of different trophic levels (e.g. PNF, ciliates, and/or dinoflagellates), we considered 2 kinds of relevant interactions during the bottle incubations: (1) copepod $\rightarrow$ dinoflagellate $\rightarrow$ nanoflagellates, and (2) copepod $\rightarrow$ 
ciliate $\rightarrow$ nanoflagellates (nanoflagellate includes both PNF and HNF). Since thecate dinoflagellates were not abundant during either the winter or spring campaigns ( $<5$ cells ml$^{-1}$, Table 2$)$, we did not consider their grazing effect to be significant in decreasing diatom cell abundance during the bottle incubations.

The unknown term in the equation of Tang et al. (2001) corresponds to the grazing effect of copepods on nanoflagellates $\left(G_{z}\right)$, when protozooplankton (ciliates or dinoflagellates) are also feeding on nanoflagellates. If the duration of the experiment is $T$, and the observed concentration of nanoflagellate cells after that time is $P_{\mathrm{f}}$ (cells $\mathrm{ml}^{-1}$ ), then $G_{\mathrm{z}}$ can be calculated using the following equation:

$G_{\mathrm{z}}=\frac{\ln \left(P_{0}\right)-\ln \left(P_{\mathrm{f}}\right)+\mu_{P}}{\mathrm{Z}}+\frac{G_{\mathrm{M}} \times \mathrm{M} \times\left[1-\exp \left(\mu_{\mathrm{M}}-h_{\mathrm{z}} \times \mathrm{Z}\right)\right]}{\mathrm{Z} \times\left(\mu_{\mathrm{M}}-h_{\mathrm{z}} \times \mathrm{Z}\right)}$

where $\mathrm{P}$ is the concentration of nanoflagellates at the start $\left(P_{0}\right)$ or end point $\left(P_{\mathrm{f}}\right)$ of the experiment, and $\mu_{P}$ is the specific growth rate of nanoflagellates. Growth rate was estimated from the differences between the initial and final times in the control bottle with seawater $<10 \mu \mathrm{m}$

Table 2. Abundance of phytoplankton and microzooplankton groups (cells $\mathrm{l}^{-1}$, mean $\pm \mathrm{SD}$ ) during winter and spring. Numerically dominant cells of each group are marked in bold

\begin{tabular}{|c|c|c|c|c|}
\hline \multirow{2}{*}{ Group } & \multicolumn{2}{|c|}{ Winter } & \multirow[b]{2}{*}{ Fjord } & \multirow{2}{*}{ - Spring $\overline{\text { Corcovado Gulf }}$} \\
\hline & Fjord & Ancud Gulf & & \\
\hline \multicolumn{5}{|l|}{ Chain-forming diatoms } \\
\hline Chaetoceros sp. & & $10 \pm 14$ & $23329 \pm 7934$ & $24583 \pm 610$ \\
\hline Chaetoceros socialis & & & $12593 \pm 7086$ & $16820 \pm 5489$ \\
\hline Chaetoceros radicans & & & $2273 \pm 893$ & $863 \pm 42$ \\
\hline Eucampia cornuta & & & $4495 \pm 223$ & $5175 \pm 1352$ \\
\hline Guinardia delicatula & & & $20233 \pm 7228$ & $29327 \pm 2457$ \\
\hline Lauderia borealis & & & $1212 \pm 1187$ & $2156 \pm 3050$ \\
\hline Leptocilindrus minimus & $12 \pm 7$ & & & \\
\hline Odontella sp. & & & $1814 \pm 676$ & $863 \pm 42$ \\
\hline Skeletonema costatum & & $550 \pm 354$ & $13902 \pm 1787$ & $22427 \pm 2521$ \\
\hline Stephanopyxis turris & $240 \pm 65$ & $70 \pm 42$ & $1450 \pm 1598$ & $863 \pm 220$ \\
\hline Thalassiosira sp. & $73 \pm 95$ & $90 \pm 70$ & $69843 \pm 23088$ & $103939 \pm 17688$ \\
\hline Thalasionema nitzschioides & $12 \pm 7$ & $10 \pm 14$ & & \\
\hline \multicolumn{5}{|l|}{ Solitary pennate diatoms } \\
\hline Amphora sp. & $13 \pm 231$ & & $2191 \pm 1265$ & \\
\hline Asterionella formosa & & & $843 \pm 1461$ & \\
\hline Cylindrotheca closterium & $12 \pm 7$ & & $1265 \pm 2191$ & $3019 \pm 4269$ \\
\hline Cymbella sp. & $12 \pm 7$ & & & \\
\hline Diploneis sp. & $13 \pm 23$ & & $3250 \pm 1686$ & $2440 \pm 1725$ \\
\hline Eunotia sp. & $35 \pm 20$ & & & \\
\hline Gomphonema sp. & $13 \pm 12$ & $20 \pm 28$ & & $431 \pm 610$ \\
\hline Gramatophora sp. & $133 \pm 122$ & $140 \pm 57$ & & \\
\hline Lichmophora abbreviata & $13 \pm 23$ & & $881 \pm 890$ & $1725 \pm 2440$ \\
\hline Navicula sp. & $76 \pm 73$ & $180 \pm 85$ & $3360 \pm 2740$ & \\
\hline Nitzschia longissima & & & $1461 \pm 843$ & \\
\hline Pinnularia sp. & $200 \pm 178$ & $160 \pm 141$ & $1054 \pm 1826$ & \\
\hline Pleurosigma sp. & & $12 \pm 7$ & $1545 \pm 1753$ & \\
\hline \multicolumn{5}{|l|}{ Pseudonitszchia sp. } \\
\hline Rhabdonema sp. & & $10 \pm 14$ & $211 \pm 365$ & \\
\hline Synedra ulna & $12 \pm 7$ & & $2707 \pm 409$ & \\
\hline \multicolumn{5}{|l|}{ Solitary centric diatoms } \\
\hline Asteromphalus sp. & $28 \pm 31$ & $14 \pm 10$ & & \\
\hline Coscinodiscus sp. & $100 \pm 35$ & $130 \pm 42$ & $696 \pm 146$ & $863 \pm 42$ \\
\hline Corethron criophilum & $20 \pm 20$ & $30 \pm 14$ & & $1294 \pm 1830$ \\
\hline \multicolumn{5}{|l|}{ Dinoflagellates } \\
\hline Dynophisis sp. & $12 \pm 7$ & & & \\
\hline Gymnodinium sp. & $48 \pm 50$ & $468 \pm 390$ & $211 \pm 365$ & \\
\hline Prorocentrum gracile & $27 \pm 46$ & $85 \pm 60$ & & \\
\hline Prorocentrum micans & & & $3256 \pm 1236$ & $2156 \pm 610$ \\
\hline Protoperidinium sp. & & & $1513 \pm 1362$ & $863 \pm 42$ \\
\hline \multicolumn{5}{|l|}{ Ciliates } \\
\hline Strombidium sp. & $14 \pm 11$ & $70 \pm 14$ & $288 \pm 498$ & $42 \pm 3$ \\
\hline Strobilidium sp. & $7 \pm 11$ & & & \\
\hline Tintinnopsis sp. & & & $996 \pm 575$ & \\
\hline Silicoflagellates & & $100 \pm 85$ & & \\
\hline
\end{tabular}


Table 3. Bottle incubation experiments for nano- and microzooplankton grazing. Natural density of predators at beginning ( $\left.T_{0}\right)$ and end $\left(T_{\mathrm{f}}\right)$ of the experiment is given (cells ml ${ }^{-1}$ ). Increase (positive values) or decrease (negative values) in predator density (\%) during the experiment and significance ( $t$-test) are also shown. HNF: heterotrophic nanoflagellates, PNF: phototrophic nanoflagellates; ${ }^{* *} \mathrm{p}<0.01$; ${ }^{*} \mathrm{p}<0.05$; n.s.: not significant, $\mathrm{p}>0.05$

\begin{tabular}{|c|c|c|c|c|c|c|c|}
\hline Expt & Date (2006) & Predator & Prey & $T_{0}$ & $T_{\mathrm{f}}$ & Differences & $\mathrm{p}$ \\
\hline \multirow[t]{3}{*}{1} & 9 July & $\mathrm{HNF}$ & Bacteria & 6.1 & 7.2 & 15.6 & ** \\
\hline & & Microzooplankton & PNF & 0.030 & 0.033 & 10.0 & $* *$ \\
\hline & & & HNF & 0.030 & 0.033 & 10.0 & ** \\
\hline \multirow[t]{3}{*}{2} & $11 \mathrm{Jul}$ & HNF & Bacteria & 6.8 & 8.0 & 15.1 & $* *$ \\
\hline & & Microzooplankton & PNF & 0.10 & 0.11 & 10.0 & $* *$ \\
\hline & & & HNF & 0.10 & 0.11 & 10.0 & $* *$ \\
\hline \multirow[t]{3}{*}{3} & $13 \mathrm{Jul}$ & $\mathrm{HNF}$ & Bacteria & 8.0 & 7.0 & -14.7 & $* *$ \\
\hline & & Microzooplankton & PNF & 0.04 & 0.05 & 24.8 & n.s. \\
\hline & & & HNF & 0.04 & 0.05 & 24.8 & n.s. \\
\hline \multirow[t]{3}{*}{6} & $4 \mathrm{Nov}$ & HNF & Bacteria & 219.6 & 266.7 & 17.7 & $* *$ \\
\hline & & Microzooplankton & PNF & 0.10 & 0.10 & 0 & $* *$ \\
\hline & & & HNF & 0.10 & 0.10 & 0 & $* *$ \\
\hline \multirow[t]{3}{*}{7} & $6 \mathrm{Nov}$ & HNF & Bacteria & 439.5 & 380.0 & -15.7 & $* *$ \\
\hline & & Microzooplankton & PNF & 0.13 & 0.14 & 5.0 & ${ }^{* *}$ \\
\hline & & & HNF & 0.13 & 0.14 & 5.0 & $* *$ \\
\hline \multirow[t]{3}{*}{8} & $8 \mathrm{Nov}$ & HNF & Bacteria & 541.1 & 511.6 & -5.8 & $* *$ \\
\hline & & Microzooplankton & PNF & 0.31 & 0.4 & 23.9 & * \\
\hline & & & HNF & 0.31 & 0.4 & 23.9 & * \\
\hline
\end{tabular}

(i.e. size fractionation experiment, Table 3). $\mathrm{Z}$ is the number of copepods, $G_{\mathrm{M}}$ is the grazing rate of microzooplankton on nanoflagellates estimated from size fractionation experiments during this study, $M$ is the microzooplankton concentration (cells $\mathrm{ml}^{-1}$ ), and $\mu_{\mathrm{M}}$ is the specific growth rate of ciliates or dinoflagellates. Growth rates of ciliates and dinoflagellates during incubations were estimated from both direct cell counts and size scaling reported for ciliates and dinoflagellates by Hansen et al. (1997). Finally, $h_{z}$ is the grazing rate by copepods on microzooplankton (ciliates or dinoflagellates). Estimations of $G_{z}$ were used to evaluate the net per capita ingestion rate of copepods on nanoflagellates during the entire experiment as suggested by Tang et al. (2001).

Field cell concentrations and biomass for protozoa and phytoplankton were estimated by means of water samples collected from the depth of the fluorescence maximum. Biomass was determined using the same methodology as outlined above.

\section{RESULTS}

\section{Environmental conditions and microbial/phytoplankton community}

The salinity profile at Stn 5 clearly shows the effect of the freshwater run-off from rivers (e.g. Puelo River) on the vertical structure of the water column in Reloncaví Fjord during our study (Fig. 2), which contrasts

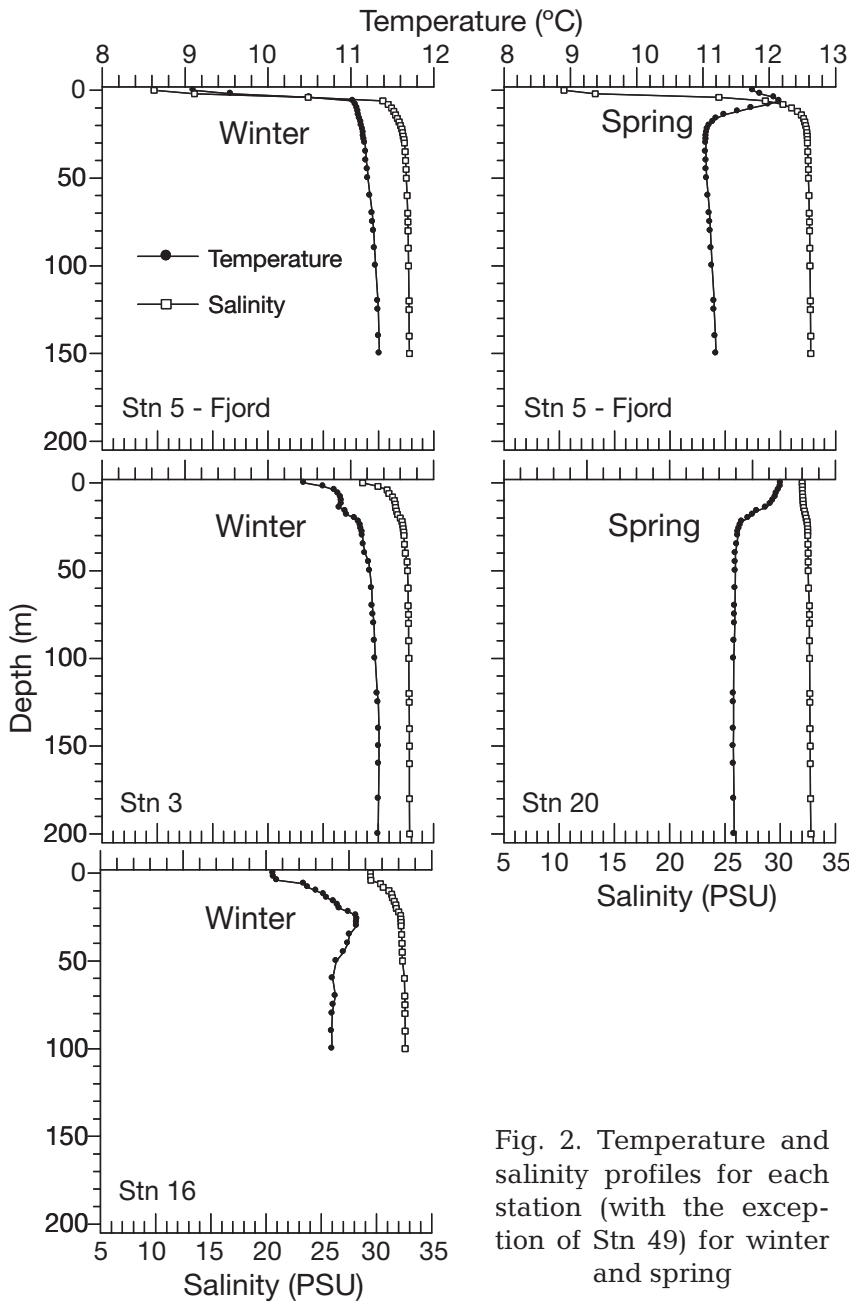


with the more homogenous water column observed in both the Ancud (Stn 3 and 16) and Corcovado Gulfs (Stn 20) (Fig. 2). In the fjord, the influence of freshwater run-off is also visible in low $\mathrm{NO}_{3}{ }^{-}$and $\mathrm{PO}_{4}{ }^{3-}$ and high $\mathrm{Si}(\mathrm{OH})_{4}$ concentrations in the brackish waters of the upper $5 \mathrm{~m}$ (Fig. 3), which suggests that, in brackish waters, the phytoplankton may be growing under $\mathrm{NO}_{3}{ }^{-}$-deficient conditions (see 'Discussion'). However, at the fluorescence maximum at $10 \mathrm{~m}$ and below (i.e. in the seawater used for the copepod incubations), $\mathrm{PO}_{4}{ }^{3-}$ and $\mathrm{NO}_{3}{ }^{-}$concentrations increased, reaching a $\mathrm{Si}: \mathrm{N}$ ratio of around 1.5 during winter and 0.3 in spring (Fig. 3). Cold surface water $\left(9\right.$ to $11^{\circ} \mathrm{C}$ ) was observed during the experiments conducted on the winter cruise, while the effect of solar radiation in spring slightly increased the temperature of the upper water column (11 to $12^{\circ} \mathrm{C}$ ). Bacterial, phytoplankton and protozoan assemblages varied drastically in abundance, composition, and biomass between both cruises, which indicates that the food environment for nano-, micro-, and mesozooplankton grazers differs significantly between winter and spring (Fig. 4). In addition, total chl a concentration (integrated over the upper $50 \mathrm{~m}$ of the water column) was highly variable, fluctuating up to 2 orders of magnitude between winter (range: 1 to $9 \mathrm{mg} \mathrm{m}^{-2}$ ) and spring (range: 52 to
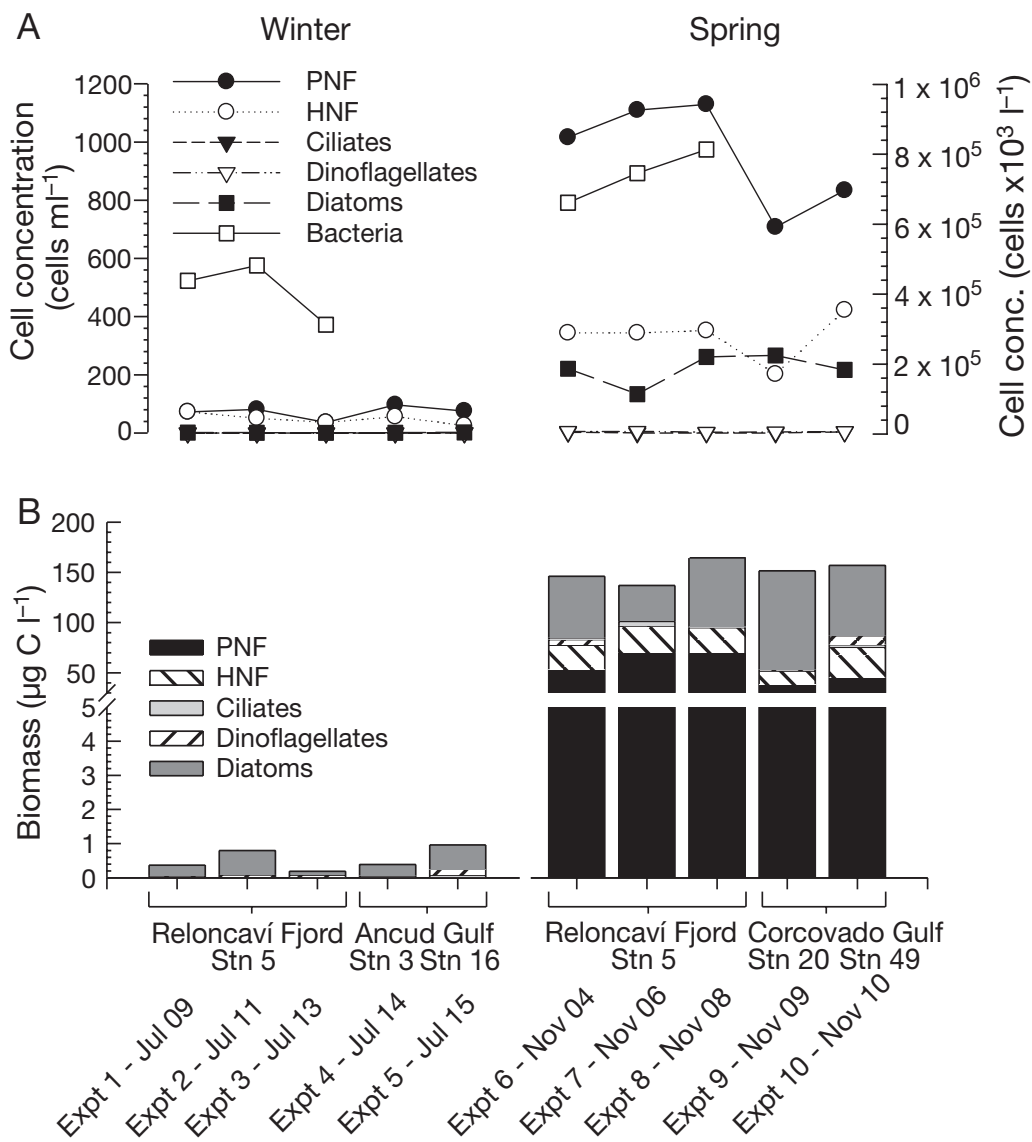

Fig. 4. Contributions of major taxonomic groups to (A) cell concentration (cells $\mathrm{ml}^{-1}$ ) and (B) biomass $\left(\mu \mathrm{g} \mathrm{C}^{-1}\right.$ ) of autotrophic and heterotrophic prey in the fluorescence maximum, corresponding to incubation water used in feeding experiments
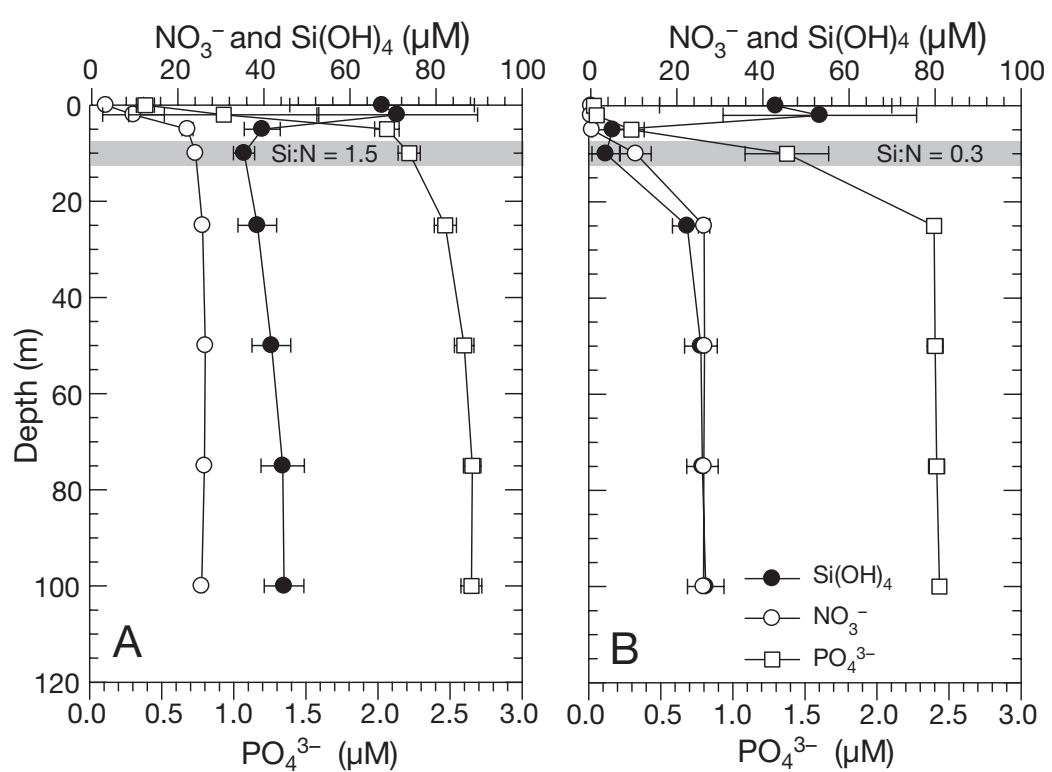

Fig. 3. Nutrient profiles of $\mathrm{NO}_{3}{ }^{-}, \mathrm{PO}_{4}{ }^{3-}$, and $\mathrm{Si}(\mathrm{OH})_{4}$ at $\mathrm{Stn} 5$ in Reloncaví Fjord (means $\pm \mathrm{SD}$ ) during $(\mathrm{A})$ winter and $(\mathrm{B})$ spring
$292 \mathrm{mg} \mathrm{m}^{-2}$ ). Main contributors to the observed chl a concentrations were the picoplankton $(<5 \mu \mathrm{m})$ in winter and netphytoplankton $(>20 \mu \mathrm{m})$ in spring, contributing 64.9 and $88.6 \%$ of total chl a concentrations, respectively (Table 4). Seasonal variability of POC in the upper $50 \mathrm{~m}$ of the water column led to concentrations being 2- to 3 -fold lower in winter (range: 4.5 to $8.4 \mathrm{~g} \mathrm{~m}^{-2}$ ) than in spring (range: 12.3 to $21.0 \mathrm{~g} \mathrm{~m}^{-2}$ ) (Table 4). During winter, cell concentration and biomass were extremely low, with values $<100$ cells $\mathrm{ml}^{-1}$ and $1 \mu \mathrm{gC} \mathrm{l} \mathrm{l}^{-1}$, respectively. Bacterial abundance ranged from 4 to $6 \times 10^{2}$ bacteria $\mathrm{ml}^{-1}$ during winter, whereas during spring, abundances were within the range of 6 to $8 \times 10^{5}$ bacteria $\mathrm{ml}^{-1}$ (Fig. $4 \mathrm{~A}$ ). The phytoplankton and protozoan community appeared to be a nanoplanktondominated system, as PNF and HNF were 
Table 4. Integrated (upper $50 \mathrm{~m}$ water column) in situ fractionated chlorophyll a ( $\mathrm{chl} \mathrm{a})\left(\mathrm{mg} \mathrm{m}^{-2}\right)$ and total particulate organic carbon (POC) concentration $\left(\mathrm{g} \mathrm{m}^{-2}\right)$ in the different plankton size fractions during winter (July 2006) and spring (November 2006) at the sampled stations in the Reloncaví fjord and adjacent areas

\begin{tabular}{|c|c|c|c|c|c|c|}
\hline \multirow{2}{*}{$\begin{array}{l}\text { Size } \\
\text { fraction }\end{array}$} & \multicolumn{3}{|c|}{$\longrightarrow$ Winter- } & \multicolumn{2}{|c|}{ Spring- } & \multirow[b]{2}{*}{ Stn 49} \\
\hline & Stn 5 & Stn 3 & Stn 16 & Stn 5 & Stn 20 & \\
\hline \multicolumn{7}{|l|}{ Chl a } \\
\hline Total & 1.06 & 2.54 & 8.91 & 291.95 & 51.99 & 120.15 \\
\hline$<5 \mu \mathrm{m}$ & 0.53 & 2.04 & 5.73 & 11.22 & 3.66 & 11.64 \\
\hline 5 to $20 \mu \mathrm{m}$ & 0.15 & 0.25 & 1.03 & 12.52 & 4.66 & 2.82 \\
\hline$>20 \mu \mathrm{m}$ & 0.37 & 0.25 & 2.16 & 271.68 & 43.66 & 105.69 \\
\hline \multicolumn{7}{|l|}{ POC } \\
\hline Total & 7.5 & 8.4 & 4.5 & 21.0 & 12.3 & 17.3 \\
\hline
\end{tabular}

the most abundant cells during the austral winter both in the fjord and in the adjacent channels (Fig. 4A). However, despite the numerical dominance of nanoplankton cells, they accounted for only a small proportion of the total biomass $\left(<0.2 \mu \mathrm{g} \mathrm{Cl}^{-1}\right)$ (Fig. 4B). Thus, the scarce diatoms, mainly represented by Skeletonema costatum, Stephanopyxis turris $(<1000$ cells $\mathrm{l}^{-1}$ ), and some small pennate diatoms such as Grammatophora sp., Navicula sp., and Pinnularia sp. (Table 2), were the main contributors to the low biomass observed during winter (ca. $1 \mu \mathrm{g} \mathrm{Cl}^{-1}$; Fig. 4B). In

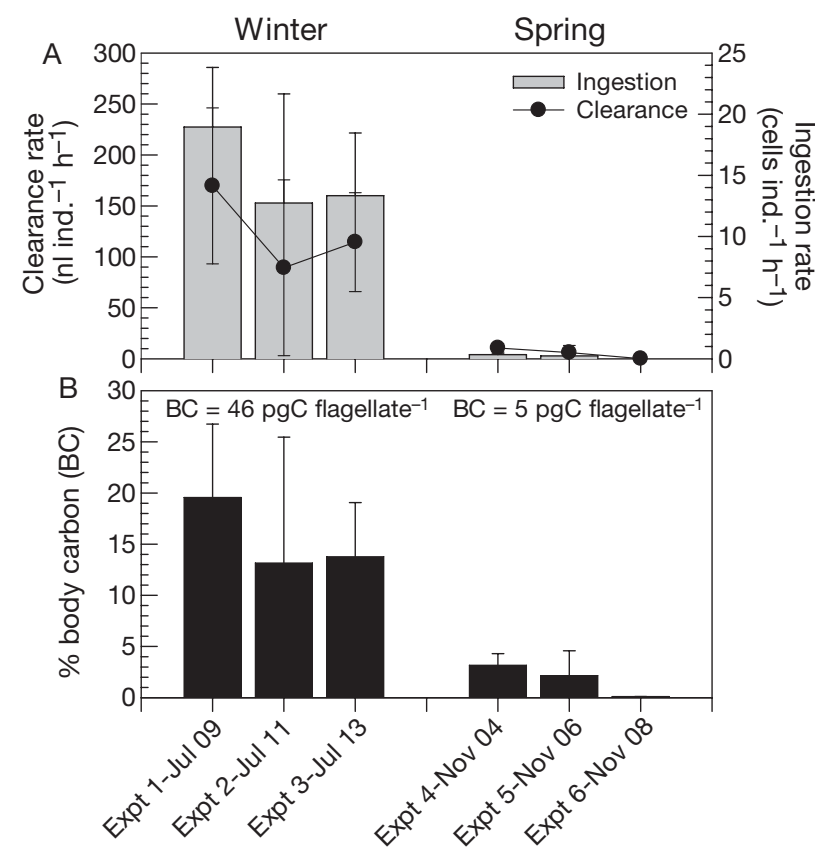

Fig. 5. Clearance (nl ind. ${ }^{-1} \mathrm{~h}^{-1}$ ) and ingestion rates (cells ind ${ }^{-1}$ $\mathrm{h}^{-1}$ ) (means $\pm \mathrm{SD}$ ) of $(\mathrm{A})$ heterotrophic nanoflagellates (HNF) $<10 \mu \mathrm{m}$ feeding on bacteria, and (B) \% of body carbon (BC) consumed daily by HNF. BC is also shown above the bars for winter and spring experiments contrast, cell concentrations during spring were significantly higher $(t$-test, $\mathrm{p}<0.01)$ with values between 200 and 1000 cells $\mathrm{ml}^{-1}$, which were numerically dominated by small nanoflagellates (mostly Cryptophyceae and Prymnesiophyceae) and diatoms (ca. 200 cells $\mathrm{ml}^{-1}$, Fig. 4). During this spring bloom, autotrophic biomass in the fjord and adjacent channels consisted primarily of diatoms (ca. $50 \mu \mathrm{g} \mathrm{C} \mathrm{l}^{-1}$ ), with Chaetoceros sp., Guinardia delicatula, and Thalassiosira spp. accounting for more than $80 \%$ of the total diatom abundance (Table 2). Ciliates and dinoflagellates were less important in terms of abundance and biomass during our study, but higher abundances of dinoflagellates and ciliates were observed during spring compared to winter (ANOVA, p < 0.01).

\section{Nanoflagellate and microzooplankton grazing}

The abundance of HNF was significantly different between cruises ( $t$-test, $\mathrm{p}<0.01$ ). The total cell numbers of HNF at the fluorescence maximum depth (10 to $20 \mathrm{~m}$ ) ranged between 7 and $8 \times 10^{3} \mathrm{HNF}^{-1}$ during winter (Table 1). In contrast, HNF abundance during spring was one order of magnitude higher in the range of 2.7 to $5.1 \times 10^{4} \mathrm{HNF} \mathrm{l}^{-1}$ (Table 1). Although some nanoflagellates could have leaked through the $2 \mu \mathrm{m}$ filter, cell counts in the initial controls clearly showed that only bacteria completely passed through this filter. Most cells in the $<10 \mu \mathrm{m}$ filter were PNF, HNF and a few small pennate diatoms. Therefore, the major grazing effect on bacteria was attributed to HNF feeding activity (or mixotrophic nanoflagellates). All experiments of nano- and micro-zooplankton grazing were conducted at Stn 5 inside the Reloncaví fjord. The number of protozoa did not change significantly ( $t$-test, $\mathrm{p}<0.01)$ throughout the incubation time, with the increase or decrease in HNF abundance between initial $\left(T_{0}\right)$ and final time $\left(T_{\mathrm{f}}\right)$ varying from 6 to $16 \%$ (Table 3 ), which falls into the background range of variance for this microscopical method (Vargas et al. 2007).

Contrasting feeding activities of HNF between winter and spring were found (Fig. 5A). During winter the ingestion rate varied from 13 to 19 bacteria ind. ${ }^{-1} \mathrm{~h}^{-1}$, and because of the low bacterial abundance, high clearance rates of 89 to $169 \mathrm{nl}$ ind..$^{-1} \mathrm{~h}^{-1}$ were observed. In contrast, during spring, the ingestion and clearance rate values decreased to between 0.01 and 0.3 bacteria ind. ${ }^{-1} \mathrm{~h}^{-1}$ and 0.2 and $10.6 \mathrm{nl}$ ind..$^{-1} \mathrm{~h}^{-1}$, respectively (Fig. 5A). Based on the calculations of cell carbon content in HNF (from cell size conversion), we estimated the percentage of their body carbon (\% BC) consumed daily during each experiment (Fig. 5B). During winter, HNF consumed between 15 to $20 \%$ BC, while BC consumption was always lower than $5 \%$ during spring. 
Relative to the $<115 \mu \mathrm{m}$ fraction, the microbial grazer community in winter consisted mainly of the small aloricate choreotrich ciliates Strombidium sp. and Strobilidium spp., and the naked dinoflagellates Gymnodnium sp. and Prorocentrum gracile (Table 2). Non-nauplii <115 $\mu \mathrm{m}$ and other large grazers were included in experimental bottles. It is likely that some large thecate dinoflagellates and tintinnids $(>115 \mu \mathrm{m})$ were not included in the major microzooplankton grazers due to this screening. However, from the analysis of the $\mathrm{T}_{0}$ samples in the copepod grazing experiments (seawater with microzooplankton $<200 \mu \mathrm{m}$ ), it was apparent that large ciliates and dinoflagellates were not present at this time in the fjord. Microzooplankton abundance did not change significantly ( $t$-test: $\mathrm{p}<$ $0.01)$ between initial $\left(T_{0}\right)$ and final time $\left(T_{\mathrm{f}}\right)$ throughout most incubation experiments $(<10 \%)$, with the exception of Expts 3 and 8, where we observed a slight increase and decrease in predator abundance, respectively; however, this amounted to less than $25 \%$ (Table 3). Microzooplankton ingestion on PNF varied from 0.02 to 0.6 cells ind ${ }^{-1} \mathrm{~h}^{-1}$, with clearance rates between 12 to $530 \mu \mathrm{l}$ ind. $^{-1} \mathrm{~h}^{-1}$ (Fig. 6). HNF were ingested at lower rates ranging from 0.01 to 0.1 cell ind. $^{-1} \mathrm{~h}^{-1}$ and with clearances less than $140 \mu \mathrm{lnd} \mathrm{i}^{-1}$ $\mathrm{h}^{-1}$. During spring, the microzooplankton community in the $<115 \mu \mathrm{m}$ fraction was comprised primarily of different species of the thecate dinoflagellates Protoperi-
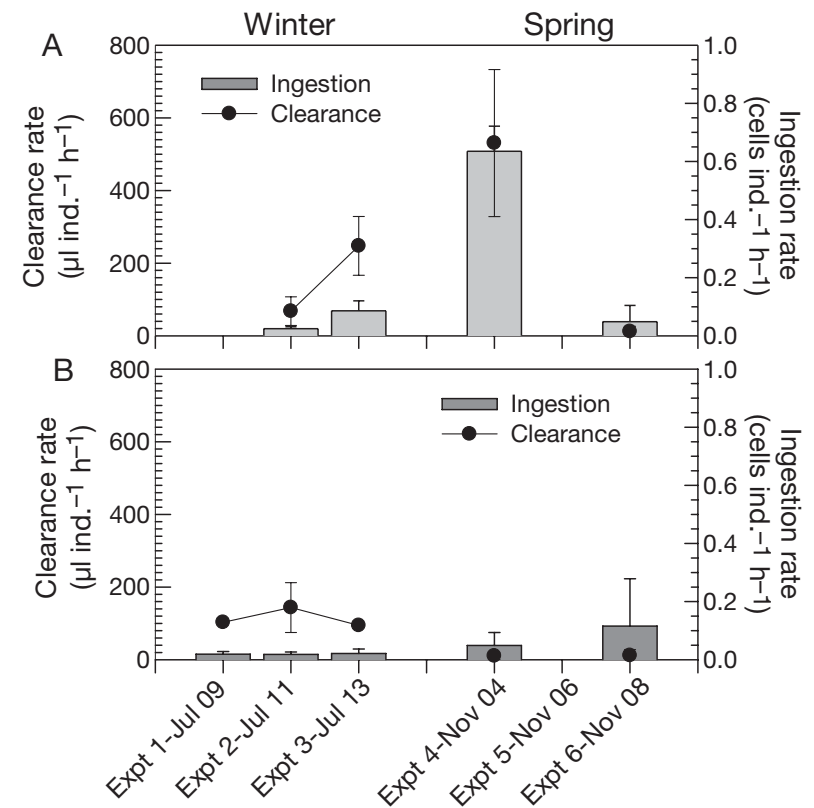

Fig. 6. Clearance $\left(\mu \mathrm{l}\right.$ ind. ${ }^{-1} \mathrm{~h}^{-1}$ ) and ingestion rates (cells ind. ${ }^{-1}$ $\mathrm{h}^{-1}$ ) of microzooplankton community $<115 \mu \mathrm{m}$ feeding on (A) phototrophic nanoflagellates (PNF) and (B) heterotrophic nanoflagellates (HNF) during both winter and spring experiments dinium sp. and Prorocentrum micans (Table 2). Ciliates were almost absent from this size fraction. Due to the increase in PNF and HNF abundance during spring, high microzooplankton ingestion was observed (Fig. 6). Ingestion rates of PNF and HNF ranged between 0.02 to 0.6 and 0.01 to 0.1 cell ind. ${ }^{-1} \mathrm{~h}^{-1}$, respectively. As a consequence, we concluded that the size-fractionation using membrane filters and different mesh sizes succeeded in creating seawater samples with differently sized grazer populations.

\section{Copepod clearance and ingestion rates}

Contrasting feeding behaviours by copepods on natural food assemblages were observed. In fact, these findings were supported by the contrasting food environments observed between winter and spring periods. In the austral winter, cell biomass was $<1 \mu \mathrm{g} \mathrm{C}$ $\mathrm{l}^{-1}$ and POC concentration was $<10 \mathrm{~g} \mathrm{~m}^{-2}$ (Fig. 4B, Table 4). During winter, copepods exhibited very low carbon ingestion rates $\left(<0.2 \mu \mathrm{g} \mathrm{C}\right.$ ind.$\left.^{-1} \mathrm{~d}^{-1}\right)$, and they were only able to support $<4 \%$ BC (Fig. 7C). Since diatoms, ciliates and dinoflagellates were very scarce during all these experiments (Fig. 4), clearance of these taxa by predators was always higher than that of small flagellates (Fig. 7). In fact, cell ingestion (data not shown) and clearance was based mostly on small PNF and HNF, but their low carbon content contributed little to total carbon ingestion by copepods $(<0.03 \mu \mathrm{g} \mathrm{C}$ ind..$\left.^{-1} \mathrm{~d}^{-1}\right)$. As a consequence, carbon ingestion was derived primarily from the ingestion of the scarce diatom chains Stephanopyxis turris, Skeletonema costatum and the small pennate diatoms Pinnularia sp. and Navicula sp. The highest carbon ingestion rates inside Reloncaví Fjord were achieved by copepodites and adults of Calanus chilensis (0.11 and $0.06 \mu \mathrm{g} \mathrm{C}$ ind. ${ }^{-1} \mathrm{~d}^{-1}$, respectively), whereas the lowest ingestion rates were observed in the adjacent Ancud Gulf (Stn 3) by Paracalanus parvus, which ingested around $0.02 \mu \mathrm{g} \mathrm{C}$ ind. ${ }^{-1} \mathrm{~d}^{-1}$ (Fig. 7C). In the Ancud Gulf (Stn 16), dinoflagellates were a major component (ca. $50 \%$ ) of the diet of the small copepods P. parvus and Acartia tonsa. Similarly low carbon ingestion values to those reported here have also been observed under foodlimitated conditions ( $<1 \mu \mathrm{g} \mathrm{C} \mathrm{l}^{-1}$ and $\left.<5 \% \mathrm{BC}\right)$ in other aquatic ecosystems (see 'Discussion' for comparison).

A completely different scenario for copepod feeding behaviour was observed during the spring campaign, when large blooms of chain-forming diatoms were observed (Fig. 4, Table 2). In spring, small and large copepods switched their diet from small flagellate cells to dinoflagellates, especially pennate and chainforming diatoms (Fig. 8C). The small copepods Paracalanus parvus and C. brachiatus ingested between 2 

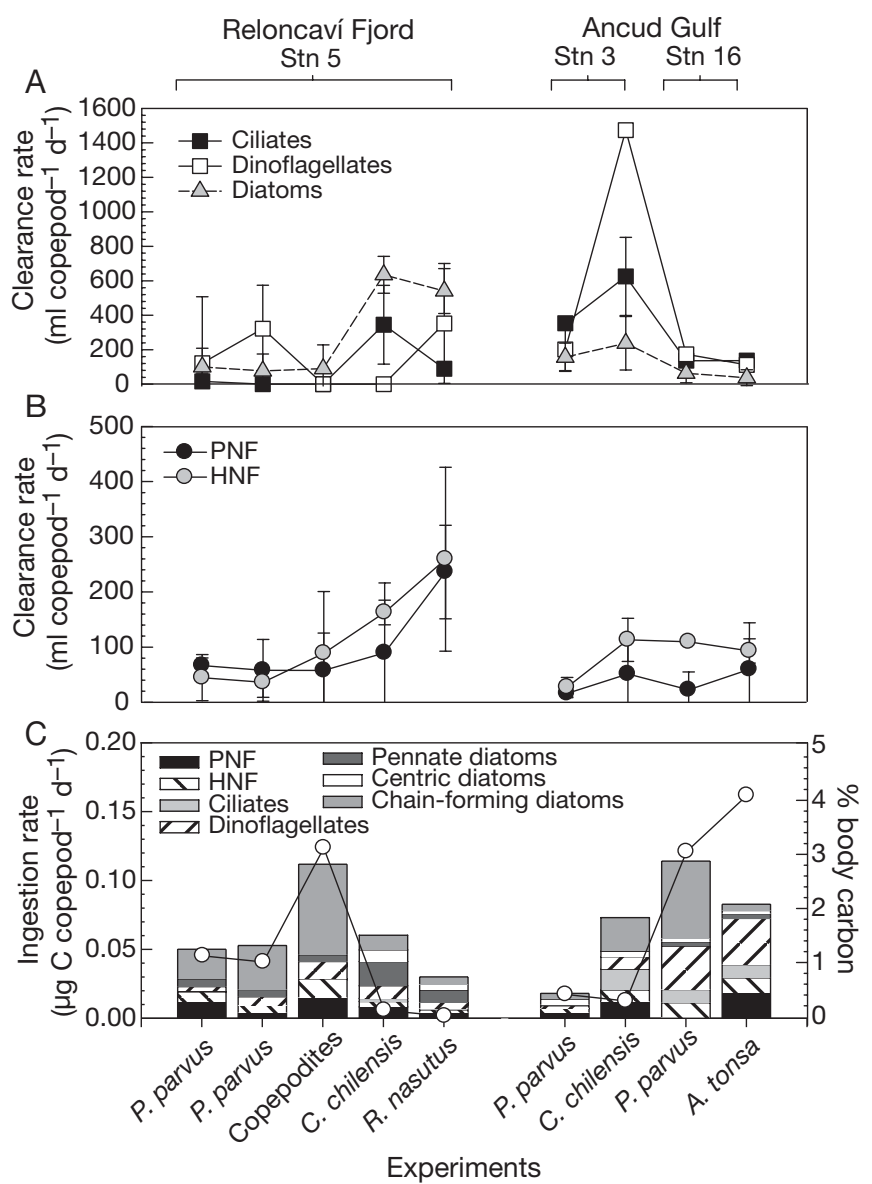

Fig. 7. Clearance rates ( $\mathrm{ml}$ copepod $^{-1} \mathrm{~d}^{-1}$, means $\pm \mathrm{SD}$ ) of copepods feeding on (A) ciliates, dinoflagellates and diatoms, and on (B) heterotrophic nanoflagellates (HNF) and phototrophic nanoflagellates (PNF). (C) Ingestion rate (in $\mu \mathrm{gC}$ copepod $^{-1} \mathrm{~d}^{-1}$ and \% body carbon consumed daily by copepods) of major autotrophic and heterotrophic groups by copepods in the austral winter at the Reloncaví Fjord and Ancud Gulf. For Stn 5, two experiments were carried out with $P$. parvus

and $3 \mu \mathrm{gC}$ ind. ${ }^{-1} \mathrm{~d}^{-1}$, whereas the large copepods Calanus chilensis, Neocalanus sp., and Rhincalanus nasutus removed between 6 and $10 \mu \mathrm{g} \mathrm{C}$ ind..$^{-1} \mathrm{~d}^{-1}$. Although diatoms constituted an important fraction of the copepod diet, PNF and HNF were cleared efficiently at higher rates by Neocalanus sp. and $R$. nasutus (from ca. 100 to $300 \mathrm{ml}$ copepod $^{-1} \mathrm{~d}^{-1}$ ) (Fig. 8A). However, PNF and HNF made a minor contribution to the total carbon ingested by Neocalanus sp. and $R$. nasutus ( $<20 \%$ of daily carbon intake), while the highest contribution was provided through the ingestion of pennate and chain-forming diatoms and, to a lesser extent, by the ingestion of large dinoflagellates (mostly Prorocentrum micans and Protoperidinium sp; Table 2 ). We did not observe significant differences in clearance and ingestion rates for either $R$. nasutus or $P$. parvus in Reloncaví fjord and Corcovado Gulf ( $t$-test, $\mathrm{p}>0.05$ ). Most small and large copepods were able to ingest more than $40 \% \mathrm{BC}$, with the exception of $R$. nasutus, which only ingested between 2 and $3 \%$ BC daily (Fig. 8C).

During winter, the selectivity index for large copepods (Calanus chilensis and Rhincalanus nasutus) suggested an active selection for large chain-forming diatoms, which were very scarce during this period (Fig. 9). This finding contrasts with observations made during spring, when the selectivity index for these large copepod species suggests a more active selection for dinoflagellates and pennate diatoms (Fig. 10). On the other hand, small copepods (e.g. Paracalanus parvus and Acartia tonsa) were more selective towards scarce mobile prey, such as dinoflagellates, during both field campaigns (Figs. 9 \& 10). The small copepod C. brachiatus exhibited an active selection for pennate diatoms during the experiments in winter (Fig. 10).
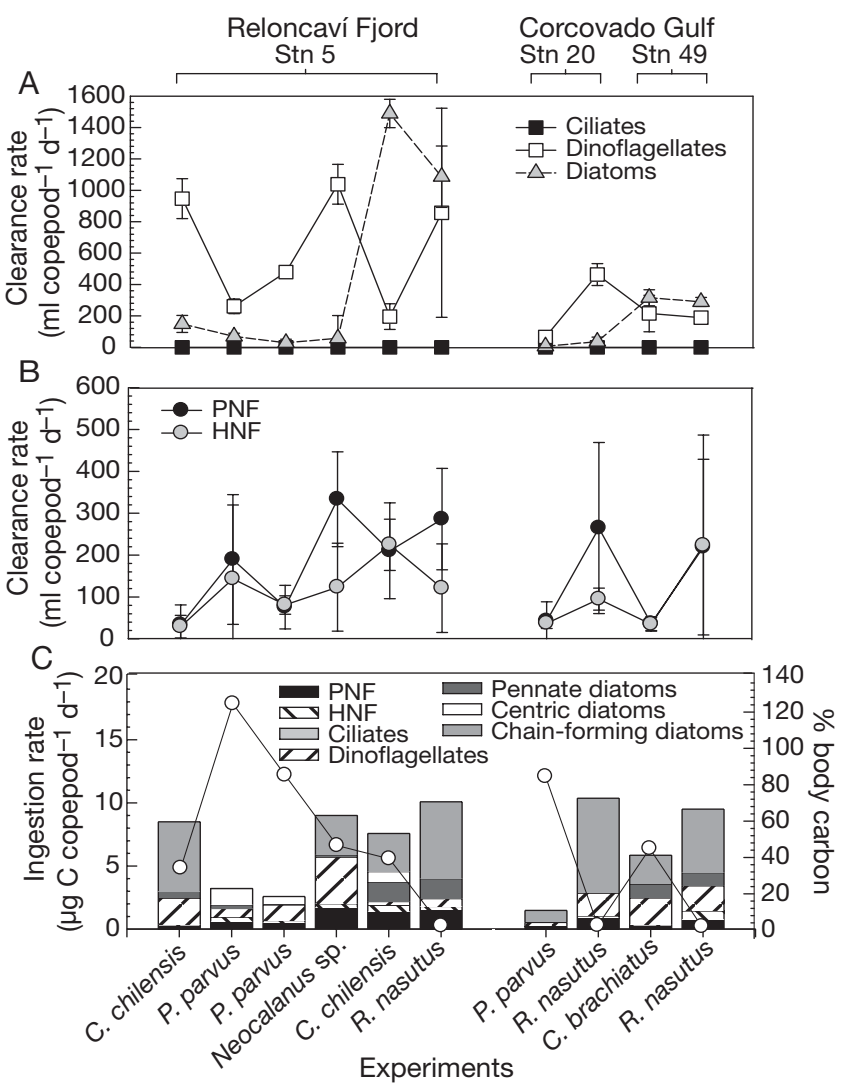

Fig. 8. Clearance rates $\left(\mathrm{ml}\right.$ copepod $\left.{ }^{-1} \mathrm{~d}^{-1}\right)$ of copepods feeding on (A) ciliates, dinoflagellates and diatoms, and on (B) heterotrophic nanoflagellates (HNF) and phototrophic nanoflagellates (PNF). (C) Ingestion rate of major autotrophic and heterotrophic groups by copepods in the austral spring bloom at the Reloncaví Fjord and Corcovado Gulf. For Stn 5, two experiments each were carried out with $P$. parvus and $C$. chilensis. See Fig. 7 for details on second $y$-axis labels in (C) 


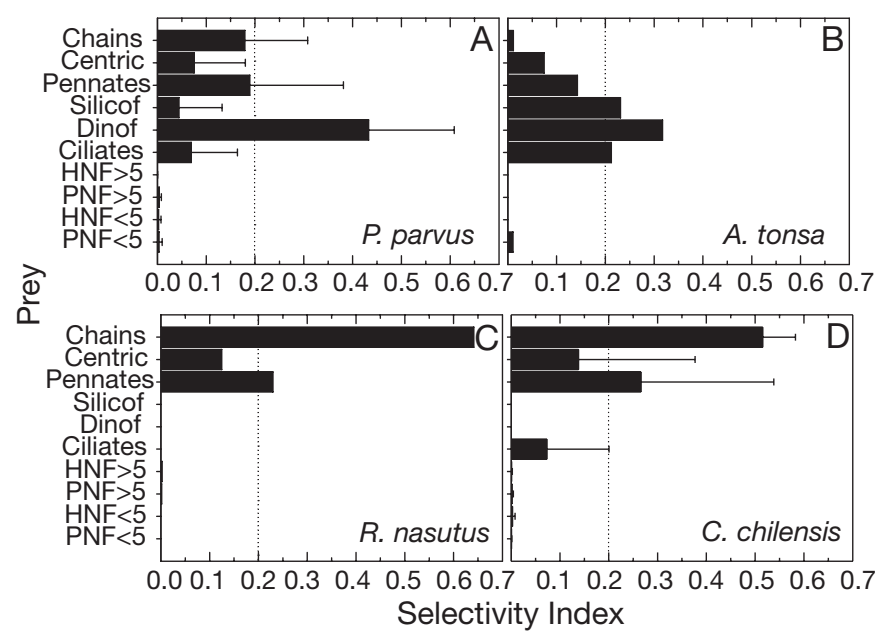

Fig. 9. Selectivity index $(\alpha$; mean \pm SD) of (A) Paracalanus parvus, (B) Acartia tonsa, (C) Rhincalanus nasutus, and (D) Calanus chilensis feeding on major autotrophic and heterotrophic groups during the austral winter in the Reloncaví Fjord and Ancud Gulf. Dotted line shows the $\alpha$-value (0.2) where no selection occurs. Chains: diatom chains; Centric: centric diatoms; Pennates: pennate diatoms.; Silicof: silicoflagellates; Dinof:dinoflagellates; $\mathrm{HNF}>5$ and $<5$ : heterotrophic nanoflagellates $>5 \mu \mathrm{m}$ and $<5 \mu \mathrm{m}_{i}$ PNF $>5$ and $<5$ : phototrophic nanoflagellates $>5 \mu \mathrm{m}$ and $<5 \mu \mathrm{m}$

\section{DISCUSSION}

\section{Seasonal variability in plankton food assemblages}

The southern Chilean fjords are characterized by strong seasonal climatic variability (e.g. solar radiation, winds, and precipitation; Acha et al. 2004), imposing an external influence on plankton communities and resulting in seasonal changes in the carbon cycling of aquatic ecosystems. Since spring blooms in high latitude coastal regions play an important role in global carbon fluxes (Liu et al. 2000), a better understanding of plankton dynamics in these regions is highly valuable. For the studied area, the little existing information concerning plankton is based mostly on individual oceanographic cruises focusing on phytoplankton (e.g. Avaria et al. 1997, Pizarro et al. 2000) and zooplankton (e.g. Palma \& Rosales 1997, Palma \& Silva 2004). As reported by other authors, we observed a large variability in the hydrographic conditions between cruises during our study, with higher temperature in the upper water column during spring. In the Reloncaví fjord, our experiments were conducted with seawater and organisms collected at the fluorescence maximum, which was located at the base of a lens of brackish cold water originating from the freshwater discharge of the Puelo River. As documented by some authors (e.g. Silva et al. 1997, 1998), we found that this estuarine and brackish water has a relatively high $\mathrm{Si}(\mathrm{OH})_{4}$ concentration, but is relatively poor in $\mathrm{NO}_{3}{ }^{-}$and $\mathrm{PO}_{4}{ }^{3-}$. In addition to the $\mathrm{NO}_{3}{ }^{-}$deficiency, there is a potential for light limitation during winter (Pizarro et al. 2000), resulting in a condition of low chlorophyll and phytoplankton biomass for planktonic grazers in the surface layer (Fig. 3). However, at the fluorescence maximum at $10 \mathrm{~m}$ depth, $\mathrm{NO}_{3}{ }^{-}$ and $\mathrm{Si}(\mathrm{OH})_{4}$ concentrations were not limiting for phytoplankton growth during either winter or spring. Similar to results reported by Iriarte et al. (2007) for this region, a low chlorophyll and pico- or nanophytoplanktondominated ecosystem was observed during our winter cruise, whereas microphytoplankton, dominated by large chain-forming diatoms, led to an extremely high phytoplankton biomass in spring (mostly belonging to the genera Thalassiosira and Chaetoceros). The constant supply of $\mathrm{Si}(\mathrm{OH})_{4}$ from river run-off (increased in spring by ice melt) probably explains the relatively high contribution of diatoms and the high rates of phytoplankton growth, as has been reported in the literature (Pizarro et al. 2000, Iriarte et al. 2007). This, in turn, may favour the abundance of planktonic omnivores and carnivores (Palma \& Silva 2004). Furthermore, the occurrence of dense blooms of long-chain forming diatoms may result in the release of large amounts of photosynthetically produced dissolved organic matter (DOM), which seems even more likely as the diatom species found during our study typically exhibit a high percentage of extracellular release of DOC (e.g. Chaetoceros spp., Nagata 2000). Consistent with this, the highest bacterial abundance was found during the spring cruise, although top-down effects of HNF grazing activity during winter may also be important in determining those differences.

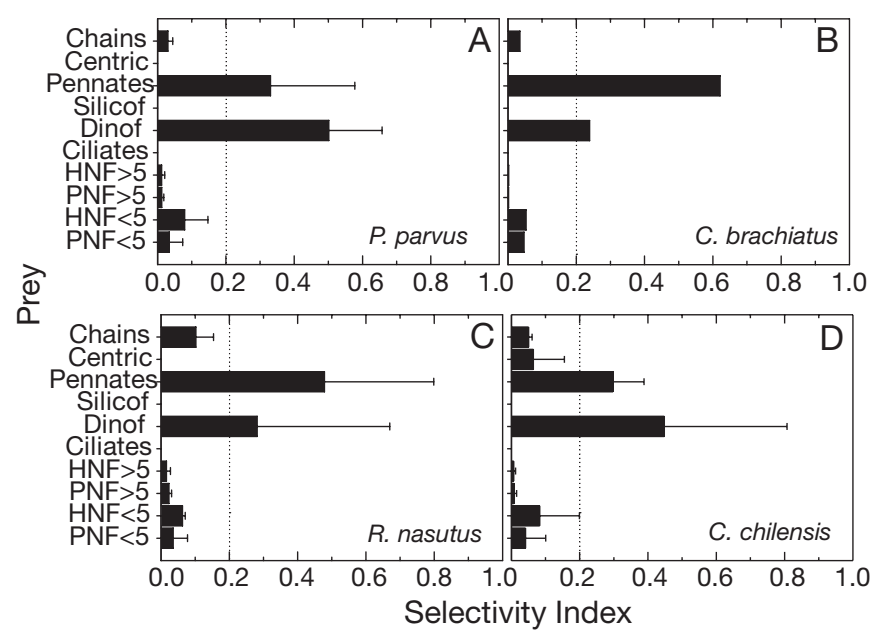

Fig. 10. Selectivity index $(\alpha$; mean \pm SD) of (A) Paracalanus parvus, (B) Centropages brachiatus, (C) Rhincalanus nasutus, and (D) Calanus chilensis feeding on major autotrophic and heterotrophic groups during the austral spring in the Reloncaví Fjord and Ancud Gulf. See Fig. 9 for other details 


\section{Feeding activity of microbial and metazoan grazers}

During both field campaigns microbial community grazers were numerically dominated by HNF. They were largely bacterivorous, and size-fractionation experiments showed that grazing by $\mathrm{HNF}<10 \mu \mathrm{m}$ was highly variable between seasons, with the highest rates during winter. During this season, bacterial abundance remained relatively low in comparison with spring, presumably because top-down processes played an important role in controlling bacterial biomass. In addition to mixotrophic nanoflagellates, HNF constitute the principal consumers of heterotrophic bacteria (Halvorsen et al. 2001), and commonly HNF ingestion may balance bacterial production and standing stock (Andersen \& Fenchel 1985). We observed extremely high ingestion rates by HNF during winter (ca. 12 to 19 cells ind.$^{-1} \mathrm{~h}^{-1}$ ), which may have resulted in heavy top-down control, which indeed was supported by the low bacterial abundance at that time. In contrast, HNF ingestion estimates during spring were at the lower end of the range reported in the literature (ca. 0.01 to 0.3 cell ind. ${ }^{-1} \mathrm{~h}^{-1}$ ). Nevertheless, our estimations were within the range of those previously reported in different studies (e.g. see Table 5), which supported the feasibility of the size-fractionation method used. For instance, Kuuppo-Leinikki (1990) using a similar methodological approach, estimated ingestion values from 2 to 27 cells ind..$^{-1} \mathrm{~h}^{-1}$. Estimations using other methods have resulted in different ranges of bacterivory, but still within the range we have found in our study. Rates reported for the 'food vacuole content' method may range between 0.9 and 6 cells ind. ${ }^{-1} \mathrm{~h}^{-1}$ (Cho et al. 2000, Christaki et al. 2002), and ca. 26 cells ind..$^{-1} \mathrm{~h}^{-1}$ by conducting experiments of Thymidine incorporation (Šolic \& Krstulović 1994). However, contrasting environmental conditions between all those studies may explain these differences. In fact, bacterivorous flagellates were comprised of a large number of taxonomically different organisms, and significant species-specific differences in the processing of food particles might explain seasonal variations in the grazing pressure by different nanoflagellate communities in the size range of 3 to $5 \mu \mathrm{m}$ (Boenigk \& Arndt 2000). Carbon ingestion for microzooplankton feeding on natural nanoplankton communities was also highly variable between seasons. Ciliates and dinoflagellates were relatively scarce during our study. In winter, microzooplankton ingestion averaged 0.5 to $1 \mathrm{ng} \mathrm{C}$ ind. ${ }^{-1} \mathrm{~h}^{-1}$, which is in agreement with rates reported in the literature (e.g. Buskey 1997 , Jeong et al. 2005). However, during spring our estimates were one order of magnitude higher than in winter (ca. $10 \mathrm{ng} \mathrm{C}$ ind. ${ }^{-1} \mathrm{~h}^{-1}$ ), which coincides with the highest abundance of nanoflagellates observed in the fjord. Nevertheless, these high ingestion values also occurred at the peak of reproduction of small copepods took place (Vargas et al. 2006). In fact, despite our careful fractionation procedure, copepod eggs were occasionally included, and the hatching of tiny nauplii

Table 5. Clearance and ingestion rates by heterotrophic nanoflagellates (HNF) and microzooplankton (ciliates and dinoflagellates) reported in the literature using different techniques. FVC: food vacuole content; FLB: fluorescently labelled bacteria; PNF: phototrophic nanoflagellates. Clearance rate given as $\mathrm{nl}$ predator ${ }^{-1} \mathrm{~h}^{-1}$ for HNF and $\left(\mu \mathrm{l}\right.$ predator ${ }^{-1} \mathrm{~h}^{-1}$ ) for all other predator groups; individual grazing rate given as cells predator ${ }^{-1} \mathrm{~h}^{-1}$

\begin{tabular}{|c|c|c|c|c|c|}
\hline Predator & Technique & Prey & $\begin{array}{l}\text { Clearance } \\
\text { rate }\end{array}$ & $\begin{array}{l}\text { Individual } \\
\text { grazing rate }\end{array}$ & Source \\
\hline \multirow[t]{10}{*}{ HNF } & $\begin{array}{l}\text { Thymidine } \\
\text { incorporation }\end{array}$ & Bacteria & 21 & 25.7 & Šolic \& Krstulović (1994) \\
\hline & FVC & FLB & $2.5-12$ & $1-6$ & Cho et al. (2000) \\
\hline & FVC & FLB & $2-12$ & $0.9-4$ & Christaki et al. (2001) \\
\hline & & Synechocchocus & $0.5-25$ & $0.003-0.1$ & \\
\hline & & Prochlorococcus & $1.2-11$ & $0.001-0.3$ & \\
\hline & FVC & Synechocchocus & $0.4-11$ & $0.0005-2.7$ & Christaki et al. (2002) \\
\hline & & Prochlorococcus & $0.2-3.4$ & $0.01-6.7$ & \\
\hline & Size-fractionation & Natural bacterioplankton & $0.6-5.3$ & $2-37$ & Kuuppo-Leinikki (1990) \\
\hline & Size-fractionation & Natural bacterioplankton & $40-300$ & Not reported & Sato et al. (2007) \\
\hline & Size-fractionation & Natural bacterioplankton & $0.2-170$ & $0.01-19$ & Present study \\
\hline Ciliates & Predator content & Tracer-level food source & $1.9-11.4$ & Not reported & I Kivi \& Setälä (1995) \\
\hline Tintinnid ciliates & FVC & PNF & Not reported & $0.16-1.14$ & Pitta et al. (2001) \\
\hline Aloricate ciliates & FVC & PNF & Not reported & $0.02-0.32$ & Pitta et al. (2001) \\
\hline \multicolumn{6}{|l|}{ Dinoflagellates } \\
\hline Gyrodinium galatheanum & FVC & Cryptophytes (PNF) & $0-0.27$ & $0-0.01$ & Li et al. (2001) \\
\hline Gyrodinium spirale & Bottle incubation & Dinoflagellates & ca. $0.4-6$ & ca. $1-14$ & Kim \& Jeong (2004) \\
\hline Protoperidinium bipes & Bottle incubation & Diatoms & ca. 1 & $0-3$ & Jeong et al. (2004) \\
\hline Microzooplankton & Size-fractionation & PNF and HNF & $11-630$ & $0.01-0.6$ & Present study \\
\hline
\end{tabular}


in the incubation bottles was observed. In the present study we have assumed that growth and clearance rates of phytoplankton are equal for different fractions. Therefore, our estimations could be also be affected by nutrient limitation effects in the bottles, and selective feeding by microzooplankton (Sato et al. 2007).

During our study, total carbon ingestion rates based on cell counts showed that copepods ingested food particles in a seasonally contrasting fashion, with values from 0.02 to 4 , and from 0.03 to $10 \mu \mathrm{g} \mathrm{C}$ ind. ${ }^{-1} \mathrm{~d}^{-1}$, for small and large copepods respectively (Figs. 7 \& 8). Our values for total carbon ingestion during winter fall into one of the lowest values for grazing estimations reported in the literature $\left(<0.2 \mu \mathrm{g} \mathrm{C}\right.$ ind. $\left.{ }^{-1} \mathrm{~d}^{-1}\right)$. However, observations for some other regions where such low particle-concentration in the water column $\left(<1 \mu \mathrm{g} \mathrm{C}^{-1}\right.$ ) has occurred have shown similar feeding behaviour. For instance, at low food concentrations of ca. $6 \mu \mathrm{g} \mathrm{C}^{-1}$ in the Greenland Sea, the large copepod Calanus glacialis removed $0.2 \mu \mathrm{g} \mathrm{C}$ ind. ${ }^{-1} \mathrm{~d}^{-1}$ (Barthel 1988). In the oligotrophic NW Mediterranean Sea, Clausocalanus spp. ingested $0.12 \mu \mathrm{gC}$ ind..$^{-1} \mathrm{~d}^{-1}$ with food concentrations of $10 \mu \mathrm{g} \mathrm{C} \mathrm{l}^{-1}$ (Broglio et al. 2004), and Temora longicornis ingested $0.1 \mu \mathrm{g} \mathrm{C}$ ind..$^{-1} \mathrm{~d}^{-1}$ in the Bay of Biscay with ca. $15 \mu \mathrm{g} \mathrm{C} \mathrm{l}^{-1}$ in the water column (D. Bonnet unpubl. data). All of these values have been reported from environments with low food concentrations; however, food concentrations were still higher than those observed during our study in winter $\left(\leq 1 \mu \mathrm{g} \mathrm{C}^{-1}\right.$ ). The results contrast dramatically with our findings during the productive spring bloom in November (ca. $200 \mu \mathrm{g} \mathrm{C}^{-1}$ ), when ingestion rates ranged from 2 to $3 \mu \mathrm{g} \mathrm{C}$ ind. ${ }^{-1} \mathrm{~d}^{-1}$ for small copepods and from ca. 6 to $10 \mu \mathrm{g} \mathrm{C}$ ind..$^{-1} \mathrm{~d}^{-1}$ for large copepods, which are relatively similar values to those reported in other productive coastal regions. In the fjord ecosystems of Bergen (Norway), Netjsgaard et al. (2001) found ingestion rates of around $13 \mu \mathrm{g} \mathrm{C}$ ind. ${ }^{-1} \mathrm{~d}^{-1}$ for Calanus finmarchicus at a food concentration of $559 \mathrm{\mu g} \mathrm{C}^{-1}$, and Paracalanus parvus ingested between 1.3 and $2.2 \mu \mathrm{g} \mathrm{C}$ ind. ${ }^{-1} \mathrm{~d}^{-1}$ in the NW Mediterranean Sea when food availability reached between 82 and $131 \mathrm{\mu g} \mathrm{Cl}^{-1}$ (Broglio et al. 2004). Thus, in such contrasting food environments, copepods have to increase the capacity to alleviate the effects of food scarcity during winter by modifying metabolic demands or by switching their diet to microbial organisms available during this period of low phytoplankton biomass. In fact, the selectivity index observed in the present study showed that, during winter, the large copepods Rhinalanus nasutus and Calanus chilensis were actively selecting scarce items, such as diatoms, whereas small copepods such as Acartia tonsa and P. parvus, were selecting other microbial prey such as dinoflagellates and ciliates. Despite selective feeding by micro-heterotrophs, copepods probably also ingested organic detritus in the poor food environment of winter in order to meet their metabolic needs and produce organic matter. Any of these assumptions suggest that zooplankton should be strongly omnivorous in these changeable estuarine/fjord ecosystems in order to survive. In contrast, since diatoms were available ad libitum during the diatom spring bloom, copepods were more selective for less abundant large prey, such as thecate dinoflagellates, and small pennate diatoms. For small copepods at least, long chain-forming diatoms (e.g. Chaetoceros and Guinardia; Table 2) might prove to be too large for passive filter-feeding behaviour. In fact, Schnack (1983) observed that copepods were unable to feed on entire colonies of Thalassiosira partheneia, which has a cell size of about $9 \mu \mathrm{m}$ but forms colonies of up to $5 \mathrm{~cm}$ in length. However, copepods consumed cells once the colonies had disintegrated. These results emphasize the importance of food availability in modulating copepod selectivity for foods that differ in nutritional quality, and suggest that such behaviour occurs in nature (Vargas et al. 2006).

One of the potential biases during our bottle incubation experiment was the 'food chain effect' (Nejstgaard et al. 2001). As the incubations proceeded, nanoflagellate growth (either PNF or HNF) in the experimental bottles could have been higher than nanoflagellate growth in the controls, because nanoflagellates in these bottles were released from microzooplankton grazing pressure as these grazers were consumed by copepods, especially during winter. This may have significant implications for the validity of copepod grazing rates obtained from traditional bottle incubation studies (e.g. Calbet \& Landry 1999 and others). This bias could have created an apparently low grazing rate on nanoflagellates, even if some copepod grazing did actually occur. However, we corrected our estimations using the 3-component equation template proposed by Tang et al. (2001), which did indeed result in grazing rates on nanoflagellates being 10 to $20 \%$ higher than uncorrected values, which are not shown. Furthermore, microzooplankton (both ciliates and dinoflagellates) were very scarce during our study $\left(<5 \mathrm{cells} \mathrm{ml}^{-1}\right)$. Thus, microzooplankton in control bottles could potentially remove ca. 0.01 to 0.6 cells $\mathrm{h}^{-1}$ from the nanoflagellates (Table 3), while 1 copepod in an experimental bottle may remove between 25 (winter) and 2000 (spring) flagellates $\mathrm{h}^{-1}$. Therefore, grazing rates on nanoflagellates were underestimated by approximately less than $10 \%$. Nutrient concentration at the fluorescence maximum where seawater was taken for the bottle incubation experiments is shown in Fig. 3. Unfortunately, nutrients were not re-sampled when the incubations were terminated. Even when surface waters were deficient in $\mathrm{NO}_{3}{ }^{-}$, at the fluorescence 
maximum $\mathrm{NO}_{3}{ }^{-}$concentration was always higher than $10 \mu \mathrm{M}$. Copepod excretion for a small copepod (e.g. Acartia australis) averages $0.0054 \mu \mathrm{g} \mathrm{N}$ ind. ${ }^{-1} \mathrm{~h}^{-1}$ (Ikeda \& Skjoldal 1980), and for large copepods (e.g. Calanus sp.) between 0.013 and $0.049 \mu \mathrm{g} \mathrm{N}$ ind. ${ }^{-1} \mathrm{~h}^{-1}$ (Ikeda \& Skjoldal 1989). As a consequence, copepods in bottle incubation might produce between 0.5 and 2 $\mu \mathrm{g} \mathrm{N} \mathrm{d}{ }^{-1}$, which means around 0.03 to $0.1 \mu \mathrm{M}$ of $\mathrm{NH}_{4}$, an insignificant amount under non-limitation nutrient conditions at the fluorescence maximum. Zooplankton grazing may also decrease silicate concentrations (Sommer 1988). However, during winter, Si:N ratios at the fluorescence maximum were near to the Redfield atomic ratio of ca. 1 . During spring, $\mathrm{Si}(\mathrm{OH})_{4}$ concentration was high enough for diatom growth $(\mathrm{Si}: \mathrm{N}$ ratio $=$ 0.3), mostly due to ice melt and high freshwater run-off from the Puelo River. Thus we conclude that the main factor causing negative uncorrected copepod grazing rates was not nutrient limitation, and trophic artefacts effects may have been partially corrected in our clearance rates estimates.

\section{Implications for carbon cycling in fjord ecosystems}

The estimations of microbial and metazoan grazing derived from the present study have important implications for carbon fluxes and ecosystem functioning in fjord areas. The low prey abundance during winter indicates that both small and large copepods were under conditions of food limitation (i.e. $<4 \%$ BC ingested daily), necessarily having to consume prey organisms from the microbial food web (e.g. small nanoflagellates). This switch in copepod diet is even more important for small copepods such as Acartia tonsa and Paracalanus parvus, which are numerically abundant year-round in the fjord area. Analyses of relative abundances in the Chilean fjord area have shown that changes in dominance occur only among the most abundant species of copepods (Marin \& Antezana 1985). Therefore, food limitation does not automatically imply starvation, population collapse, and copepod succession; because the low ingestion rates observed at that time may be compensated for by the catabolism of lipid reserves, typical of large copepods from high latitudes (e.g. Calanus sp., Rhincalanus sp., and Neocalanus sp.; Mauchline 1998). Much remains to be understood about the mechanisms that planktonic organisms have for addressing food limitation conditions in aquatic ecosystems or whether we are missing a major component of the system (Saiz \& Calbet 2007).

Integrated bacterial and PP estimates conducted during the same field campaign (G. Daneri \& J. L. Iriarte unpubl. data, respectively) for the upper $20 \mathrm{~m}$, euphotic layer, showed that both bacterial and PP were much higher during spring conditions (300 and $1893 \mathrm{mg} \mathrm{C} \mathrm{m}{ }^{-2} \mathrm{~d}^{-1}$, respectively). During winter, bacteria were heavily grazed on by HNF, which reached maximum ingestion rate values (Fig. 5), and then by ciliates, dinoflagellates, or copepods. In fact, more than $50 \%$ of the daily carbon ingested by small copepods (Paracalanus parvus and Acartia tonsa) originated from heterotrophs. Therefore, small copepods may transfer bacterial carbon of different origins (autochthonous and/or allochthonous) towards higher trophic levels. A contrasting scenario was observed during spring. The low HNF ingestion values observed during spring were not expected, considering that the highest bacterial production was found during the same period. However, most of the HNF cells at that time corresponded to small cells $(<4 \mu \mathrm{m})$ with reduced ingestion rates in comparison to the larger flagellates in winter. In addition, in a study of the role of mixotrophic organisms in Chilean fjord ecosystems (T. Czypionka unpubl. data), maximum grazing activity by mixotrophs occurred during winter, when there is a strong light limitation on photosynthetic activity. During spring/summer, a large part of the mixotrophic community (considered to be heterotrophic cells) acts principally as autotrophic organisms rather than grazers. Similar evidence has also been found for nanoflagellate communities in other aquatic ecosystems (e.g. Palsson \& Graneli 2003).

During spring, more than $50 \%$ of the copepod diet consisted of long-chain forming diatoms (i.e. mostly Chaetoceros, Guinardia delicatula and Thalassiosira sp.). However, the present study revealed that in fjord ecosystems, even during productive spring bloom conditions, the less-abundant heterotrophic protists (i.e. HNF and microzooplankton) also constituted a substantial proportion of the copepod diet (ca. $30 \% \mathrm{~d}^{-1}$ ). Therefore, some of the carbon from bacterial and protozoan production may enter the path to larger zooplankton and, in turn, to large metazoans (e.g. fish larvae). Given the high abundance of small copepods in these fjord ecosystems (Marín \& Antezana 1985, Hirakawa 1989), omnivory would also suppress microbial food webs and enable zooplankton to use small picoplankton and convert it to exportable biogenic carbon (Vargas et al. 2007), an important link that needs to be considered in future plankton studies and food web models of fjord ecosystems. The main seasonal trend in the pelagic ecosystem seems to be the succession from a classical to a microbial-mediated food web. Thus, our results, although limited in terms of spatial coverage, provide strong evidence that the food web structure in this fjord ecosystem could be classified as multivorous (Vargas \& González 2004b), where herbivorous and microbial grazing modes both have 
significant roles in carbon export, depending on the external influence of the strong seasonal climatic variability (e.g. solar radiation, winds, and nutrient loading). Furthermore, simultaneous measurements of production, biomass, grazing, and respiration loss within both the microbial loop and the classical food chain are necessary to elucidate material cycling and to verify the role of the microbial loop in fjord ecosystems.

Acknowledgements. We thank the captains and crew of RV 'Vidal Gormaz' and the graduate students who participated in our cruises (i.e. especially to L. A. Cuevas, E. Menschel, and M. J. Calderón). We also thank C. Cartes for their help during the laboratory analyses and T. Czypionka for valuable suggestions that substantially improved an earlier version of the manuscript. We also thank 3 reviewers for very constructive comments on the manuscript. Financial support for this study was provided by the CIMAR Fiordos Program Project No. CONA-C12F 06-10. Fondecyt Project $N^{\circ} 1060709$ to C.A.V. supported this research during the final preparation of the manuscript.

\section{LITERATURE CITED}

Acha EM, Mianzan HW, Guerrero RA, Favero M, Bava J (2004) Marine fronts at the continental shelves of austral South America: physical and ecological processes. J Mar Syst 44:83-105

Andersen P, Fenchel T (1985) Bacterivory by microheterotrophic flagellates in seawater samples. Limnol Oceanogr 30:198-202

Antezana T, Hamamé M (1999) Short-term changes in the plankton of a highly homogeneous basin of the Straits of Magellan (Paso Ancho) during spring 1994. Sci Mar 63: 59-67

Atlas E, Hager S, Gordon L, Park P (1971) A practical manual for use of the Technicon Autoanalyzer in seawater nutrient analyses. Technical Report, Dept. of Oceanography, Oregon State University, Corvallis, OR

Avaria S, Cassis D, Muñoz P, Vera P (1997) Distribución del microfitoplancton marino en aguas interiores del sur de Chile en octubre de 1995 (Crucero Cimar 1 Fiordos). Cienc Tecnol Mar 20:107-123

Barthel KG (1988) Feeding of three Calanus species on different phytoplankton assemblages in the Greenland Sea. Meeresforschung 32:92-106

Bodungen BV, Wunsch M, Fürderer H (1991) Sampling and analysis of suspended and sinking particles in the northern North Atlantic. In: Spencer DW, Hurd DC (eds) Marine particles: analysis and characterization. AGU Geophys Monogr 63:47-56

Boenigk J, Arndt H (2000) Comparative studies on the feeding behaviour of two heterotrophic nanoflagellates: the filterfeeding choanoflagellate Monosiga ovata and the raptorial-feeding kinetoplastid Rhynchomonas nasuta. Aquat Microb Ecol 22:243-249

Broglio E, Saiz E, Calbet A, Trepat I, Alcaraz M (2004) Trophic impact and prey selection by crustacean zooplankton on the microbial communities of an oligotrophic coastal area (NW Mediterranean Sea). Aquat Microb Ecol 35:65-78

Burrell DC (1988) Carbon flow in fjords. Oceanogr Mar Biol Annu Rev 26:143-226

Buskey EJ (1997) Behavioral components of feeding selectivity of the heterotrophic dinoflagellate Protoperidinium pellucidum. Mar Ecol Prog Ser 153:77-89

Calbet A, Landry MR (1999) Mesozooplankton influences on the microbial food web: direct and indirect trophic interactions in the oligotrophic open ocean. Limnol Oceanogr 44:1370-1380

Chesson J (1978) Measuring preference in selective predation. Ecology 59:211-215

Christaki U, Giannakourou A, Wambeke FV, Grégori G (2001) Nanoflagellate predation on auto- and heterotrophic picoplankton in the oligotrophic Mediterranean Sea. J Plankton Res 23:1297-1310

Christaki U, Courties C, Karayanni H, Giannakourou A, Maravelias C, Kormas KAr, Lebaron P (2002) Dynamic characteristics of Prochlorococcus and Synechococcus consumption by bacterivorous nanoflagellates. Microb Ecol 43:341-352

Chrzanowski TH, Šimek K (1990) Prey-size selection by freshwater flagellated protozoa. Limnol Oceanogr 35: 1429-1436

Edler L (1979) Recommendations for marine biological studies in the Baltic Sea. Baltic Mar Biol Publ 5:1-38

Frost BW (1972) Effects of size and concentration of food particles on the feeding behaviour of the marine planktonic copepod Calanus pacificus. Limnol Oceanogr 17:805-815

Gifford DJ (1993) Consumption of protozoa by copepod feeding on natural microplankton assemblages. In: Kemp PF, Sherr BF, Sherr EB, Cole JJ (eds) Handbook of methods in aquatic microbial ecology. Lewis Publishers, London, p 723-737

Gifford DJ, Caron DA (2000) Sampling, preservation, enumeration and biomass of marine protozooplankton. In: Harris RP, Wiebe PH, Lenz J, Skjoldal HR, Huntley M (eds) ICES Zooplankton methodology manual. Academic Press, London, p 193-221

Gorsky G, Dallot S, Sardou J, Fenaux R, Carré C, Palazzoli I (1988) C and $\mathrm{N}$ composition of some northwestern Mediterranean zooplankton and micronekton species. J Exp Mar Biol Ecol 124:133-144

Haas LW (1982) Improved epifluorescence microscopy for observing planktonic micro organisms. Ann Inst Oceanogr 58:261-266

Halvorsen E, Pedersen OP, Slagstad D, Tande KS, Fileman ES, Batten SD (2001) Microzooplankton and mesozooplankton in an upwelling filament off Galicia: modelling and sensitivity analysis of the linkages and their impact on the carbon dynamics. Prog Oceanogr 51:499-513

Hansen PJ, Bjørnsen PK, Hansen BW (1997) Zooplankton grazing and growth: scaling within the $2-2000 \mu \mathrm{m}$ body size range. Limnol Oceanogr 42:687-704

Hirakawa K (1989) Planktonic copepods from Aysen Fjord and adjacent waters, southern Chile. Proc NIPR Symp Polar Biol 2:46-50

Ikeda T, Skjoldal HR (1980) The effect of laboratory conditions on the extrapolation of experimental measurements to the ecology of marine zooplankton. VI. Changes in physioilogical activities and biochemical components of Acetes sibogae australis and Acartia australis after capture. Mar Biol 58:285-293

> Ikeda T, Skjoldal HR (1989) Metabolism and elemental composition of zooplankton from the Barents Sea during early Arctic summer. Mar Biol 100:173-183

Iriarte JL, González HE, Liu KK, Rivas C, Valenzuela C (2007) Spatial and temporal variability of chlorophyll and primary productivity in surface waters of southern Chile $\left(41.5-43^{\circ} \mathrm{S}\right)$. Estuar Coast Shelf Sci 74:471-480

> Jeong HJ, Yoo YD, Seong KA, Kim JH and others (2005) Feeding by the mixotrophic red-tide dinoflagellate 
Gonyaulax polygramma: mechanisms, prey species, effects of prey concentration, and grazing impact. Aquat Microb Ecol 38:249-257

Kivi K, Setälä O (1995) Simultaneous measurement of food particle selection and clearance rates of planktonic oligotrich ciliates (Ciliophora: Oligotrichina). Mar Ecol Prog Ser 119:125-137

Liu KK, Iseki K, Chao SY (2000) Continental margin carbon fluxes. In: Hanson RB, Duklow HW, Field J (eds) The changing global ocean carbon cycle. International geosphere-biosphere programme book series 5, Cambridge University Press, p 187-239

Marín V, Antezana T (1985) Species composition and relative abundance of copepods in Chilean fjords. J Plankton Res 7:961-966

Mauchline J (1998) The biology of calanoid copepods. Academic Press, San Diego, CA

Nagata T (2000) Production mechanisms of dissolved organic matter. In: Kirchman DL (ed) Microbial ecology of the oceans. Wiley-Liss, New York, p 121-152

- Nejstgaard JC, Naustvoll LJ, Sazhin A (2001) Correcting for underestimation of microzooplankton grazing in bottle incubation experiments with mesozooplankton. Mar Ecol Prog Ser 221:59-75

Nielsen TG, Andersen CM (2002) Plankton community structure and production along a freshwater-influenced Norwegian fjord system. Mar Biol 141:707-724

Ohman MD, Snyder RA (1991) Growth kinetics of the omnivorous oligotrich ciliate Strombidium sp. Limnol Oceanogr 36:922-935

Palma S, Silva N (2004) Distribution of siphonophores, chaetognaths, euphausiids and oceanographic conditions in the fjords and channels of southern Chile. Deep-Sea Res II 51:513-535

Palsson C, Graneli W (2003) Diurnal and seasonal variations in grazing by bacterivorous mixotrophs in an oligotrophic clear-water lake. Arch Hydrobiol 157:289-307

Parsons TR, Maita Y, Lalli CM (1985) A manual of chemical and biological methods for seawater analysis. Pergamon Press, Oxford

Pizarro G, Iriarte JL, Montecino V, Blanco JL, Guzmán L (2000) Distribución de la biomasa fitoplanctónica y productividad primaria máxima de fiordos y canales australes $\left(47^{\circ}-50^{\circ} \mathrm{S}\right)$ en octubre 1996. Cienc Tecnol Mar 23:25-47

Saiz E, Calbet A (2007) Scaling of feeding in marine copepods. Limnol Oceanogr 52:668-675

Editorial responsibility: Ruben Sommaruga, Innsbruck, Austria
Sato M, Yoshikawa T, Takeda S, Furuya K (2007) Application of the size-fractionation method to simultaneous estimation of clearance rates by heterotrophic flagellates and ciliates of pico- and nanophytoplankton. J Exp Mar Biol Ecol 349:334-343

Schnack SB (1983) On the feeding of copepods on Thalassiosira partheneia from the northwest African upwelling area. Mar Ecol Prog Ser 11:49-53

Silva N, Calvete C, Sievers HA (1997) Características oceanográficas físicas y químicas de canales australes chilenos entre Puerto Montt y Laguna San Rafael (Crucero Cimar- Fiordo 1). Cienc Tecnol Mar 20:23-106

Silva N, Calvete C, Sievers HA (1998) Masas de agua y circulación general para algunos canales australes entre Puerto Montt y Laguna San Rafael, Chile (Crucero Cimar-Fiordo 1). Cienc Tecnol Mar 21:17-48

Šolić M, Krstulović N (1994) Role of predation in controlling bacterial and heterotrophic nanoflagellate standing stocks in the coastal Adriatic Sea: seasonal patterns. Mar Ecol Prog Ser 114:219-235

Sommer U (1988) Phytoplankton succession in microcosm experiments under simultaneous grazing pressure and resource limitation. Limnol Oceanogr 33:1037-1054

Tang KW, Jakobsen HH, Visser AW (2001) Phaeocystis globosa (Prymnesiophyceae) and the planktonic food web: feeding, growth, and trophic interactions among grazers. Limnol Oceanogr 46:1860-1870

Tiselius P (1989) Contribution of aloricate ciliates to the diet of Acartia clausi and Centropages hamatus in coastal waters. Mar Ecol Prog Ser 56:49-56

- Vargas CA, González HE (2004a) Plankton community structure and carbon cycling in a coastal upwelling system. I. Bacteria, microprotozoans and phytoplankton in the diet of copepods and appendicularians. Aquat Microb Ecol 34: 151-164

> Vargas CA, González HE (2004b) Plankton community structure and carbon cycling in a coastal upwelling system. II. Microheterotrophic pathway. Aquat Microb Ecol 34: 165-180

Vargas CA, Escribano R, Poulet S (2006) Phytoplankton diversity determines time-windows for successful zooplankton reproductive pulses. Ecology 87:2992-2999

Vargas CA, Martínez R, Cuevas LA, Pavez M and others (2007) The relative importance of microbial and classical food webs in a highly productive coastal upwelling area. Limnol Oceanogr 52:1495-1510

Submitted: March 3, 2008; Accepted: August 26, 2008

Proofs received from author(s): October 29, 2008 